Research article

\title{
Stakeholder engagement in the study and management of invasive alien species
}

\author{
Ross T. Shackleton a, b, c, *, Tim Adriaens ${ }^{\text {d }}$, Giuseppe Brundu ${ }^{\text {e, }}$ \\ Katharina Dehnen-Schmutz ${ }^{\mathrm{f}}$, Rodrigo A. Estévez ${ }^{\mathrm{g}}$, Jana Fried ${ }^{\mathrm{f}}$, Brendon M.H. Larson ${ }^{\mathrm{b}}$, \\ Shuang Liu ${ }^{\mathrm{h}}$, Elizabete Marchante ${ }^{\mathrm{i}}$, Hélia Marchante ${ }^{\mathrm{i}, \mathrm{j}}$, Moleseng C. Moshobane ${ }^{\mathrm{k}}$, \\ Ana Novoa ${ }^{\mathrm{a}, \mathrm{l}, \mathrm{m}}$, Mark Reed ${ }^{\mathrm{n}}$, David M. Richardson ${ }^{\mathrm{a}}$ \\ ${ }^{a}$ Centre for Invasion Biology, Department of Botany and Zoology, Stellenbosch University, Matieland 7602, South Africa \\ ${ }^{\mathrm{b}}$ School of Environment, Resources and Sustainability, University of Waterloo, Waterloo, Ontario N2L3G1, Canada \\ ${ }^{c}$ Institute of Geography and Sustainability, University of Lausanne, 1015 Lausanne, Switzerland \\ ${ }^{\mathrm{d}}$ Institute for Nature and Forest Research (INBO), Brussels, Belgium \\ e Department of Agriculture, University of Sassari, 07100 Sassari, Italy \\ ${ }^{\mathrm{f}}$ Centre for Agroecology, Water and Resilience, Coventry University, Coventry, United Kingdom \\ g Centre of Applied Ecology and Sustainability (CAPES), Departamento de Ecología, Pontificia Universidad Católica de Chile, O'Higgins 340, Santiago, Chile \\ h CSIRO Land and Water Flagship, GPO Box 1700, Canberra ACT 2601, Australia \\ ${ }^{\mathrm{i}}$ Centre for Functional Ecology, Department of Life Sciences, University of Coimbra. Calçada Martim de Freitas, $3000-456$ Coimbra, Portugal \\ ${ }^{\mathrm{j}}$ Escola Superior Agrária, Instituto Politécnico de Coimbra, Bencanta, 3045-601 Coimbra, Portugal \\ ${ }^{\mathrm{k}}$ Directorate of Biological Invasions, South African National Biodiversity Institute, Pretoria National Botanical Garden, 2 Cussonia Avenue, Brummeria, \\ Silverton, Pretoria, South Africa \\ ${ }^{1}$ Institute of Botany, The Czech Academy of Sciences, Department of Invasion Ecology, CZ-252 43 Prühonice, Czech Republic \\ $\mathrm{m}$ Invasive Species Programme, South African National Biodiversity Institute, Kirstenbosch Research Centre, Private Bag x7, Claremont, 7735, South Africa \\ ${ }^{n}$ School of Natural and Environmental Sciences, HEFCE N8 Agri-Food Resilience Programme, Institute for Agri-Food Research and Innovation and Centre for \\ Rural Economy, Newcastle University, NE1 7RU, United Kingdom
}

\section{A R T I C L E I N F O}

\section{Article history:}

Received 9 October 2017

Received in revised form

29 March 2018

Accepted 9 April 2018

Available online 1 August 2018

\section{Keywords:}

Biological invasions

Collaboration

Environmental management

Human dimensions

Global review

Natural resource management

Participation

Social-ecological systems

\begin{abstract}
A B S T R A C T
Invasive alien species are a major driver of global environmental change and a range of management interventions are needed to manage their effects on biodiversity, ecosystem services, human well-being and local livelihoods. Stakeholder engagement is widely advocated to integrate diverse knowledge and perspectives in the management of invasive species and to deal with potential conflicts of interest. We reviewed the literature in the ISI Web of Science on stakeholder engagement (the process of involving stakeholders (actors) in decision making, management actions and knowledge creation) in invasion science to assess and understand what has been done (looking at approaches and methodologies used, stakeholders involved, and outcomes from engagement) and to make recommendations for future work.

Research on stakeholder engagement in invasion science has increased over the last decade, helping to improve scientific knowledge and contributing towards policy formulation and co-implementation of management. However, many challenges remain and engagement could be made more effective. For example, most studies engage only one stakeholder group passively using questionnaires, primarily for assessing local knowledge and perceptions. Although useful for management and policy planning, these stakeholders are not active participants and there is no two-way flow of knowledge. To make stakeholder involvement more useful, we encourage more integrative and collaborative engagement to (1) improve co-design, co-creation and co-implementation of research and management actions; (2) promote social learning and provide feedback to stakeholders; (3) enhance collaboration and partnerships beyond the natural sciences and academia (interdisciplinary and transdisciplinary collaboration); and (4) discuss some practical and policy suggestions for improving stakeholder engagement in invasion science research and management. This will help facilitate different stakeholders to work better together allowing problems associated with biological invasions to be tackled more holistically and successfully (C) 2018 Elsevier Ltd. All rights reserved.
\end{abstract}

\footnotetext{
* Corresponding author. Institute of Geography and Sustainability, University of Lausanne, 1015 Lausanne, Switzerland.

E-mail address: rtshackleton@gmail.com (R.T. Shackleton).
} 


\section{Introduction}

Ecosystems and human well-being are increasingly under threat from the inter-connected challenges of climate change, land degradation, pollution, invasive alien species and other drivers which are bringing us closer to exceeding the world's planetary boundaries (Vitousek et al., 1997; Rockström et al., 2009; Steffen et al., 2015). Dynamic interactions between these drivers of change in social-ecological systems make environmental management and conservation issues extremely complex, not least because they require equal consideration of both ecological and social processes (Reed, 2008; Ostrom, 2009). This is particularly important in invasion science - the study of the causes and consequences of the introduction of organisms outside their native ranges by humans, some of which spread (become invasive) and cause impacts to humans and the environment (Richardson and Ricciardi, 2013; Jeschke et al., 2014). Invasion science exemplifies this complexity because tackling the challenge of invasive species depends as much upon the perceptions, attitudes and behaviour of stakeholders as it does on the ecology of how an invasive alien species spreads or causes impact (Bremner and Park, 2007; Larson, 2007; Wesselink and Paavola, 2011; Pyšek et al., 2012, Jeschke et al., 2014, Reed and Curzon, 2015; Woodford et al., 2016; Hui and Richardson, 2017; Shackleton et al., 2018a). For example, there are often conflicts of interest between stakeholders surrounding the management of invasive species due to trade-offs between costs and benefits surrounding economic, social and environmental factors and intrinsic issues (van Wilgen and Richardson, 2012, 2014; Seastedt, 2014; Estévez et al., 2015; Novoa et al., 2016; Zengenya et al., 2017). New frameworks and approaches for resolving these issues ("conflicts of interest") are urgently needed and are starting to be developed (Gaertner et al., 2016; Ricciardi et al., 2017; Novoa et al., 2018). Other specific challenges have been identified that relate to stakeholders' lack of knowledge and awareness surrounding invasive species (Colton and Alpert, 1998; Reis et al., 2011; Shackleton and Shackleton, 2016; Novoa et al., 2017), concerns regarding the ethics of some management approaches (Estévez et al., 2015; Seastedt, 2014), and poor cooperation between different stakeholders (Novoa et al., 2016; Shackleton et al., 2016). As a result, researchers are paying more attention to the role of stakeholder engagement in the management of biological invasions to improve the long-term effectiveness and efficiency of invasive species management.

The role of stakeholder engagement is increasingly being recognised in environmental decision-making, including national and international policy formulation (Reed, 2008; Novoa et al., 2015; Sterling et al., 2017). For example, the Convention on Biological Diversity and the European Strategy on Invasive Alien Species, which underpins European Union regulations (Genovesi and Shine, 2004; Genovesi et al., 2015), both explicitly recognize the need for stakeholder engagement. Engagement is important for understanding perceptions and practices, promoting awareness and social learning, building collaborative research, reaching consensus and agreements, solving conflicts, aiding prioritisation and planning and formulating co-management programs (Stokes et al., 2006; García-Llorente et al., 2008; Reed, 2008, Reed et al., 2009; Dehnen-Schmutz et al., 2010; Touza et al., 2014; Bryce et al., 2011; Liu et al., 2010; Fischer et al., 2014; Adriaens et al., 2015a; Novoa et al., 2016; Gaertner et al., 2017; Bravo- Vargas et al. 2019). For example, engagement has led to successful co-management of invasive mink (Nevison vison) in Scotland (Bryce et al., 2011), has reduced conflicts of interest and improved consensus regarding the management of invasive cacti in South Africa (Novoa et al., 2016), has promoted collaborative research and awareness through citizen science projects and monitoring in Europe (Adriaens et al., 2015a;
Marchante et al., 2017), and has aided planning and prioritisation of the management of European house borer (Hylotrupes bajulus) in Australia (Liu et al., 2010).

We define a stakeholder as any individual, group or organisation who is affected (positively or negatively) by invasive species, or who has the capacity to promote or limit the spread of invasive species (after Freeman, 1984). Stakeholders include the public/citizens (affected by and/or responsible for the spread and/or control of invasive species), researchers, government departments (responsible for the management of invaded areas or as policy makers), non-governmental organisations (NGOs), businesses and industry, and many other groups (Friedman and Miles, 2006; Wesselink and Paavola, 2011; Reed and Curzon, 2015; Novoa et al., 2017). We define stakeholder engagement as the process of involving stakeholders (actors) in decision making, management actions and knowledge creation surrounding invasive species. Depending on the environmental governance framework within which engagement takes place and the goals it seeks to reach, engagement may vary in terms of its agency, being initiated and facilitated from the top-down by external agencies, bottom-up by affected communities, or some combination of the two (Reed et al., 2017). It may also vary in terms of the mode of engagement, including unidirectional communication (the one-way flow of information from the initiator to other stakeholders), consultation (the one-way flow from the stakeholder to the initiator), deliberation (the backward and forward/bidirectional flow of information between multiple stakeholders) and co-production (the joint production of knowledge to inform jointly-owned decisions) (Reed et al., 2017). Through engagement, stakeholders can provide various inputs (e.g. human, social and/or financial capital, knowledge and expertise) and be involved at different stages of the process of invasive species management.

We used a bibliometric approach to review the status of stakeholder engagement in invasion science to assess current trends and progress with respect to their social, ecological and geographic scope, the engagement methods used and the outcomes of engagement. Several narrowly focused review/synthesis assessments have addressed stakeholder engagement and invasive alien species (e.g. Estévez et al. (2015) focusing on animals only; Stokes et al. (2006) focusing only on the situation in Ireland) relating to the topic, but a broad review and synthesis is lacking. This paper highlights current trends, strengths and weaknesses of stakeholder engagement related to invasive alien species, as reported in the literature, and we conclude by identifying four themes/topics that deserve attention to ensure a better integration of stakeholder engagement in invasion research and management.

\section{Methodology}

We conducted a keyword search ("alien"," invasive", "exotic", AND "stakeholder", "social”, "human", "engagement", "participation") in the ISI Web of Science covering titles, keywords and abstracts with no specified time span of publication in June 2017. We acknowledge that other databases searches might have yielded slightly different results (Higgins and Green, 2011; Falagas et al., 2008), but we chose to use the ISI Web of Science following the approach used by many similar review papers on the topic of invasion biology and forms of engagement and conservation management (e.g. Silvertown, 2009; Lowry et al., 2013; Estévez et al., 2015; Vaz et al., 2017a). All papers were pre-reviewed to ensure relevance. We excluded those that did not deal with invasive alien species, as well as several reviews, theoretical or opinion pieces. We only included as "case studies" those papers that involved actual engagement in various forms with stakeholders as described in the papers methodology (examples of excluded papers are Kull et al., 
2011 - synthesis type paper, Shackleton and Gambiza, 2008 - not on invasive alien species, but a native weedy plant). As with most literature-search based studies, our search was conducted in English. This might result in a geographical bias of the literature and miss a number of studies although there are already high research biases across different regions (for example with a lot less in South America (Speziale et al., 2012; Nunez and Pauchard, 2010)) and also the increased tendency globally for researchers to publish in international journals (in English). We also acknowledge that a large number of engagement interactions are not published in peerreviewed journals and might therefore have been missed by our search. Our aim was to focus specifically on what is happening in the scientific research domain and so we chose to use ISI rather than other platforms such as Google Scholar which also covers the grey literature. In total, we included 121 case studies/papers of stakeholder engagement in relation to invasive species - our sample size is similar to that of a recent study on a similar topic (Estévez et al., 2015). The papers were distributed among the coauthors to review according to a very specific data-extraction template that sought to avoid bias and differences in interpretation between reviewers (Appendix 1). The approach to the study and data extraction template was fine-tuned and adjusted over several rounds of consultation with all co-authors based on the collaboratively designed aims and objectives of the paper. A measure to highlight a reviewer's uncertainty for some answers was included; papers or specific answers were thus flagged and were later checked and resolved by the co-ordinating assessor. We did not include a measure of review consistency (e.g. kappa statistics) as the information (data) was relatively straightforward and not likely to be highly subject to bias (most categories were predefined). Also, the data extraction template was carefully designed and co-created by all authors to avoid bias (Higgins and Greens, 2011).

Information was extracted from each paper to assess (1) the broad context and trends of biological invasion research and invasive alien species targeted in studies regarding stakeholder engagement, and (2) the stakeholder engagement processes and outcomes in the scientific research. The extracted information on the context and trends included, specifically, information on (1a) the characteristics of the target species; (1b) the social, ecological and geographic descriptors of where studies were conducted; (1c) the pathways of introduction of the target species; and (1d) the effects of invasive alien species (different kinds of benefits and costs for humans and the environment - which also provides important information regarding the context of engagement). This information focused on gaining a better understanding of the socialecological background of invasive species studied or managed using stakeholder engagement, to try identify any key trends. Regarding the stakeholder engagement processes and outcomes, the extracted information included (2a) the reasons for engagement; (2b) the engagement approaches/methods; (2c) the stakeholder groups (actors) engaged; and (2d) the identification of the level of engagement and any successes and failures or issues faced in the research or from the engagement process (this was done to understand the processes of stakeholder engagement in the field) (see Appendix 1 for more details).

\section{Key findings}

\subsection{Trends in the reviewed literature over time}

As with research on invasion science in general (see Richardson and Pyšek, 2008), the number of publications addressing stakeholder engagement in issues regarding biological invasions has grown markedly over the last decade; only two studies were identified before the year 2000 (Fig. 1). Research on this topic, however, lags behind other themes in invasion science, like invasion ecology (Vaz et al., 2017b; Abrahams et al., 2019). For example, ecological research on invasions started to boom in the 1980s and 1990s and many more papers on ecological issues are published annually than those relating to social issues concerning invasions (Richardson and Pyšek, 2008; Lowry et al., 2013; Foxcroft et al., 2017; Vaz et al., 2017b). The growing number of scientific papers now being published on the topic is a useful indicator, showing the increasing awareness of the importance of stakeholder engagement in the management of environmental issues - although the increased research interest might not translate directly into measures to actively increase and promote engagement. The growth of research on stakeholder engagement in invasion science may also link with the increasing recognition of the importance of social and human dimensions in the field (e.g. McNeely, 2001). For example, the research focus in invasion science in protected areas has shifted over time, with increases in studies that incorporate social aspects after 2005 (Foxcroft et al., 2017). This is also reflected in the results of the assessment by Estevez et al. (2015) which shows a sharp rise in the number of publications on social dimensions in invasion science after 2000, along with a steep rise generally in all literature on biological invasions. A boom in stakeholder engagement with regards to biological invasions (Fig. 1) after 2009 may also coincide with the increasing recognition of social-ecological systems research and governance and the need for interdisciplinary research, which was especially promoted with the emergence of the concept of ecosystem services in the 2000s (ME, 2005; Ostrom, 2009). It might also link with the publication of seminal papers acknowledging the need for stakeholder engagement in environmental management and conservation in the mid-late 2000s (Keen et al., 2005; Stringer et al., 2006; Reed, 2008; Reed et al., 2009), as well as some similar works on defining and understanding the phenomenon of biological invasions (e.g. Pyšek et al., 2004; Richardson and Pyšek, 2006). A call for the need and importance of increasing social research and engagement relating to climate change and management was highlighted in a special issue on the topic in 2000 which likely mirrors trends in invasion science (Trumbo and Shanahan, 2000).

\subsection{Social, ecological and geographical contexts of research on stakeholder engagement}

Case studies on stakeholder engagement in invasion science were dispersed across a number of countries and island states

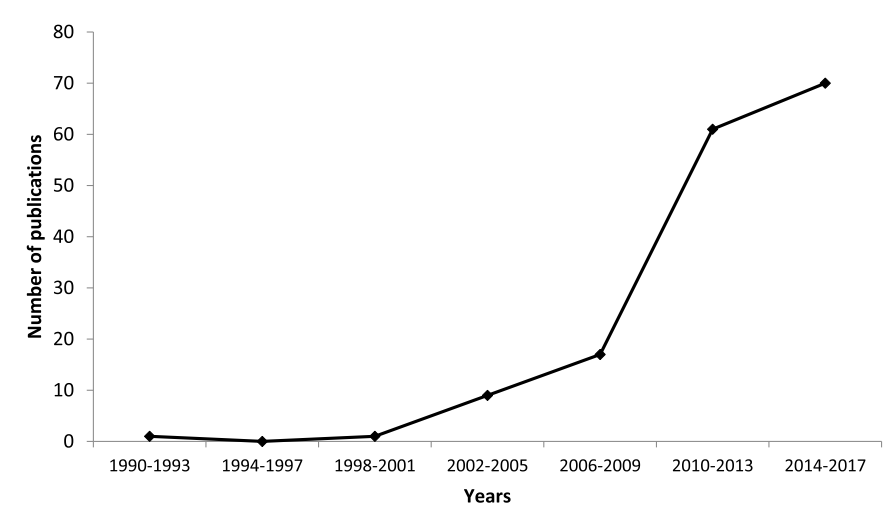

Fig. 1. Trends in peer-reviewed publications dealing with stakeholder engagement in invasion science over time based on the results from the search made on ISI Web of Science. 
around the world, representing different social-ecological contexts and states of development (Fig. 2). The majority of research has, however, been undertaken in relatively few countries, with seven countries (South Africa and the USA primarily, along with Australia, Canada, India, Spain and the UK) contributing nearly three quarters of this work (73\%). Interestingly, these countries correspond closely with the global invasion hotspots (Dawson et al., 2017), but also with regions with a long history of research in invasion science, such as former British Overseas Territories, as opposed to South American countries (Speziale et al., 2012). Similar issues with bias in research have also been noted in ecological research in general (Buchadas et al., 2017). As noted, these results might also be slightly biased due to the English-only searches. More developed nations also often have higher research outputs in the field which links to a number of factors, but especially funding and capacity for research (Nunez and Pauchard, 2010). Engagement also took place at different scales. About two-thirds of the studies were conducted at local or regional levels (35\% and 38\%, respectively), 18\% nationally, and only $8 \%$ internationally, across multiple countries (e.g. Binimelis et al., 2007; van der Wal et al., 2015).

Almost all aquatic and terrestrial biomes were covered in the case studies analysed. Most studies encompassed a number of different biomes (29\%), followed by freshwater rivers, lakes or dams (16\%) and Mediterranean-type ecosystems, temperate forests, grasslands or savannas ( $9 \%$ each). Furthermore, the majority of studies covered multiple land-tenure types (41\%), followed by those that were focussed on private rangelands and protected/ conservation areas (both 17\%), agricultural fields and urban areas (both $9 \%$ ) and communal lands (7\%). In general, multiple land uses were covered in the studies as invasions were widespread affecting different areas. There was also a particular interest in protected areas which is common in invasion science (being an ecological/ biological discipline) and where invasive species are seen to cause substantial impact (Hulme et al., 2014; Foxcroft et al., 2017). Few studies focused on agricultural systems, as they are private lands where conservation and research institutions may have less access (Hilty and Merenlender, 2003) and many studies focused on native weeds.

\subsection{Invasive species covered in stakeholder engagement research}

\subsubsection{Pathways on invasive species studied}

The reviewed sources covered a large number of different pathways of introduction of the target invasive species. The most common reason for introduction was for ornamental purposes (16\%), followed by accidental introductions (14\%), agriculture (13\%), agroforestry (9\%), forestry (7\%) and recreational purposes (7\%), with aquaculture, the pet trade, restoration, soil improvement, soil stabilisation, and hedging also being mentioned. For $19 \%$ of the case studies, the pathway or reason of introduction was unknown or unclear; in most cases, such introductions were likely to be accidental. The studies mentioned different invasive species that have been introduced over a number of centuries, including introductions in the early 1800s (Kannan et al., 2014) through to 2001 (Binimelis et al., 2007). Having a good understanding of the pathways of introduction can help to identify key stakeholders to engage as well as procedures for engagement, and crucial management actions to prevent spread. For example, engagement surrounding the management of invasive species introduced as ornamental plants might be conducted very differently compared to those which arrived through agricultural activities. These species are valued and perceived differently and might lead to different kinds of conflicts - i.e. economic vs aesthetic value. Furthermore, considering pathways may help engage stakeholders to implement specific management strategies, for example, education and awareness raising among recreational boaters regarding the spread of aquatic invasive species in lakes around the USA (Cole et al., 2016; Cole et al., 2019).

\subsubsection{Invasive alien species targeted in engagement research and management}

The level or extent of invasion of the species considered in the reviewed case studies varied, with most studies focusing on regionally or nationally abundant species (26\% and $17 \%$ respectively), followed by locally abundant (14\%) and localised sparse/ scattered species (9\%). Nearly a quarter of studies (23\%) did not mention the level of invasion. Traditionally, widespread species

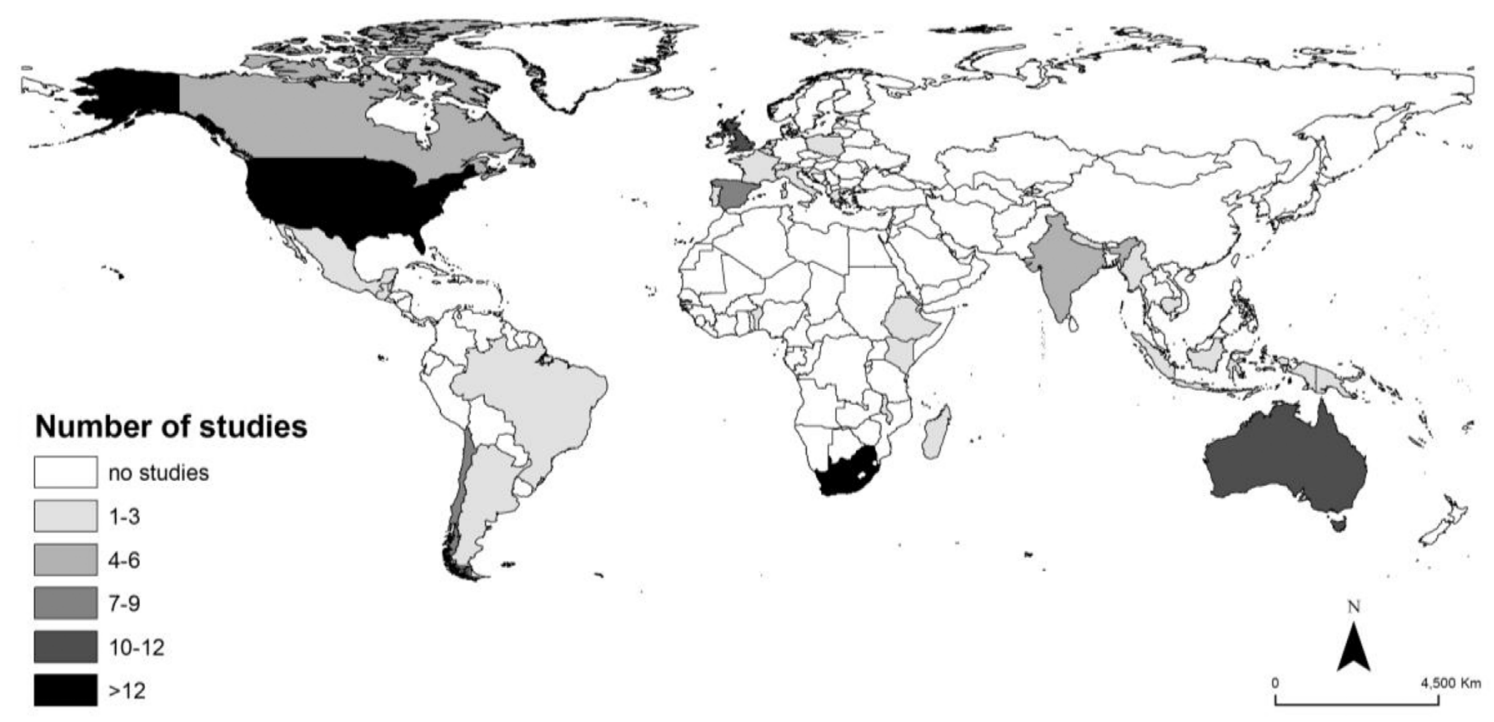

Fig. 2. Country-level contributions to stakeholder engagement research in invasion science. 
need the greatest amount of engagement for research and management as they most likely have more substantial effects on humans and the environment. However, it is important to engage stakeholders about emerging invasive species and species that are not widely spread, especially if engagement is aimed at shaping early detection and rapid response management options. This can provide support to managers and research, for example for mapping and removing species. Moreover, some narrowly dispersed invasive species can also create conflicts of interest around the management techniques used (Gaertner et al., 2016). Linking engagement to pathway management to prevent the spread of narrowly distributed species is also crucial (see above).

A relatively large proportion of studies (30\%) focussed on a number of different species (more than 10) or taxonomic groups (i.e. ornamental plants or invasive fish) (e.g. Dehnen-Schmutz et al., 2010; Halford et al., 2014; Sharpe, 2014), whereas most studies focused on one or a small number of invasive taxa (Table 1 ). The genera Acacia and Prosopis were commonly studied because they are two of the most widespread invasive tree taxa globally (Rejmanek and Richardson, 2013) and they provide substantial economic benefits and costs that result in well-documented conflicts of interest (Richardson et al., 2011; Mwangi and Swallow, 2008; van Wilgen and Richardson, 2014; Shackleton et al., 2015). For example, Mwangi and Swallow (2008) in Kenya and Shackleton et al. (2015) in South Africa engaged local communities to understand the relative benefits and costs of Prosopis for local livelihoods and to support decision making. Four species among the top ten were animals (Table 1); this is because their management is often contentious due to debates relating to the intrinsic value of the species and the ethics of management methods, especially relating to animal welfare (Bremner and Park, 2007; Estévez et al., 2015; Villatoro et al., 2019) - including species such as American mink (N. vison) in Cape Horn, Chile (Schüttler et al., 2011), grey squirrel (Sciurus carolinensis) in the UK (Barr et al., 2002), and wild boar (Sus scrofa) in Texas, USA (Perry and Perry, 2008). Other commonly studied species were zebra mussel (Dreissena polymorpha), Japanese knotweed (Fallopia japonica) and hydrilla (Hydrilla verticillata) which have less benefits and potentially lower conflicts of interest, unlike some of the other species listed in Table 1. However, using engagement-related studies to understand the impacts of these (and other) species on people and the environment is useful for providing evidence of impacts and can help with decision making and support management (Binimelis et al., 2007; Limburg et al., 2010; Monteroso et al., 2011). It can also help to raise awareness and improve collaborations for managing such high-impact species (Novoa et al., 2017). Furthermore, engagement with stakeholder improved knowledge of the introduction and spread of invasive species which can help to prioritise preventive actions (Cole et al., 2016; 2019).

\subsection{Benefits and costs of studied species}

In many of the case studies, the species in question had multiple benefits and costs for society and for the environment (Fig. 3). Especially relating to ecosystem services and human well-being issues, a number of benefits and costs were raised which mirrored work by Vaz et al. (2017a), Shackleton et al. (2018b) and Potgieter et al. (2019). For example, invasive trees such as Australian acacias and Prosopis species provide direct benefits such as fuelwood, fodder and the improvement of soil quality, but they also induce health and safety issues and can cause loss of ecosystem services such as grazing potential or non-timber forest products which can have negative economic consequences (Kull et al., 2011; Shackleton et al., this issue). Some species also provide intrinsic costs and/or benefits relating to aesthetic and humanistic values (van der Wal et al., 2015). Negative impacts on biodiversity were mentioned in almost all case studies, whereas benefits relating to biodiversity were rarely mentioned. The exception was Finch and Baxter (2007), who found that landowners in Australia wanted to retain invasive deer as a component of biodiversity for future generations to enjoy (Fig. 3). The lack of reporting benefits of invasive alien species for biodiversity could be because many invasive species provide no benefits for biodiversity or because in general invasion science often focuses on understanding the negative impacts (Tassin and Kull, 2015). The scale of invasion is often a confounding factor with regards to the level and perceptions of benefits and costs and the need for engagement, the need often being greater for more widespread and established species. However, there can still be issues with narrowly distributed species that do require engagement to reduce conflicts and or/improve management, for example with Himalayan tahr (Hemitragus

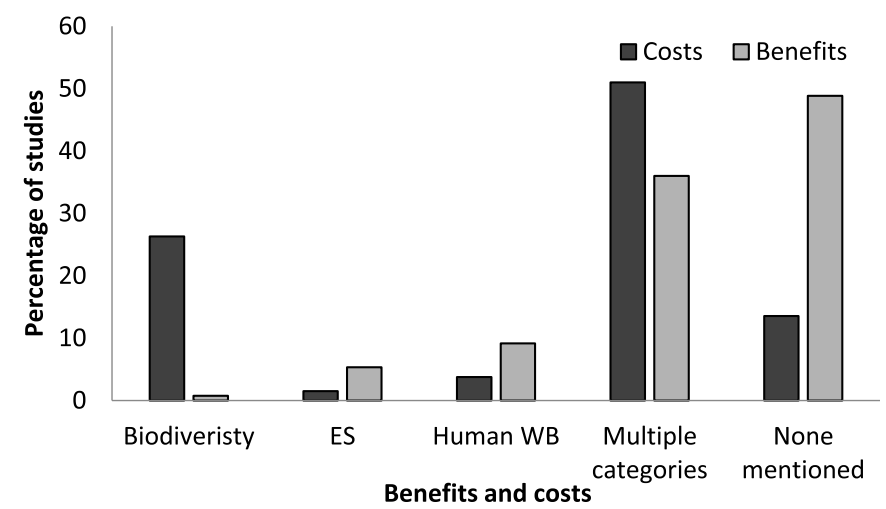

Fig. 3. Benefits and costs of invasive species identified in 121 published case studies that detail aspects of stakeholder engagement, including benefits and costs relating to biodiversity, ecosystem service(s) (ES's, including supporting and regulating services, provisioning services and cultural services), and impacts on human well-being (WB).

Table 1

The top 10 most studied invasive taxa in stakeholder engagement studies.

\begin{tabular}{lll}
\hline Rank & Species or genus & Common name \\
\hline 1 & Acacia species & Wattles \\
2 & Prosopis species & Mesquite \\
3 & Lantana camara & Lantana \\
4 & Dreissena polymorpha & Zebra mussel \\
5 & Fallopia japonica & Japanese knotweed \\
6 & Neovison vison & American mink \\
7 & Sus scrofa & Feral Pig/Wild Boar \\
8 & Mikania micrantha & Mile-a-minute vine/bitter vine \\
9 & Sciurus carolinensis & Grey squirrel \\
10 & Hydrilla verticillata & Hydrilla \\
\hline
\end{tabular}


jemlahicus) (C. H. Smith, 1826) on Table Mountain in South Africa (Gaertner et al., 2016). Furthermore, to promote early detection and rapid response initiatives aiming to tackle new and emerging invasive species, engagement is crucial for awareness raising and improving participation in management, especially if the species is present on private land.

Species providing both benefits and costs can often complicate decisions on management and therefore require stakeholder engagement to improve understanding, reduce conflicts of interest and build collaboration and cohesion. Novoa et al. (2016) showed that stakeholder engagement was needed to build consensus regarding the management of cacti species in South Africa, as they have both benefits arising from their use as ornamental plants, fodder and food, as well as negative impacts on biodiversity, ecosystem services and human well-being, loss of rangeland potential, loss of cultural services (recreation), access to land and injuries to humans and animals. The engagement process fostered social learning both by those in favour and those opposed to the management (active control or prevention) of cacti invasion, leading to increased consensus and effective policy formulation.

\subsection{The status of stakeholder engagement in invasion science}

\subsubsection{Reasons for engagement}

The reviewed studies mentioned different reasons for engagement, and many invoked a number of different goals (Table 2). The majority of studies focused on understanding people's specific knowledge and perceptions of the target invasive species (76\%) which can be important for guiding management implementation (see Shackleton et al. (2018a) for definitions and need to understand people's perceptions regarding management of biological invasions). For example, there were studies looking at people's knowledge and perceptions of different invasive plants in urban gardens in South Africa (Shackleton and Shackleton, 2016), as well as an assessment of people's perceptions towards different control techniques for invasive alien species as seen in a case study in Poland (Olszańska et al., 2016). Gathering information to improve the scientific understanding of the target species was also a common objective (66\% of studies). Gauging attitudes towards species is a fundamental requirement for understanding stakeholders' value systems and is needed prior to management planning and implementation. Informing policy and management planning and decision making (41\%) was also a common goal for many studies, as seen for planning invasive plant management in the Western Cape, South Africa (Forsyth et al., 2012), and for the European house borer (Hylotrupes bajulus) in Australia (Liu et al., 2010). A number of goals were related to the involvement of stakeholders in collaborative research and management, and citizen science $(23 \%)$ in which the involvement of stakeholders was a fundamental component of data collection or implementing management actions, which in turn helps to build social learning and co-ownership of projects. For example, collaborative control between a number of actors to manage the invasive mink in Scotland (Bryce et al., 2011), and using smartphones for citizen science reporting of invasive species in Europe (Adriaens et al., 2015a). A number of studies also aimed to build cohesion and consensus among stakeholders (11\%) (e.g. Novoa et al., 2016). This is very important for species with conflicts of interest surrounding their management, as seen with cactus species used for ornamental purposes, fodder and food in South Africa but that also impact grazing and have human and animal health issues (Novoa et al., 2016). Similarly, the AlterIAS LIFE + project in Belgium worked with a number of horticultural stakeholders to co-develop a code of conduct with consensus from all parties for the nursery industry to reduce the threat of invasive alien species (Halford et al., 2014). The reasons mentioned to a lesser extent in Fig. 4 are often more integrative and included in long-term projects, such as citizen science monitoring and reporting programs and volunteer research and management implementation (see Marchante et al., 2017; Pagès et al., 2019).

\subsubsection{Engagement methodology}

The most common method of engagement was the use of questionnaires (61\%, Table 2 ). This is a passive form of engagement involving the one-way flow of information from the stakeholder to the initiator in a consultative mode (Reed, 2008; Reed et al., 2017). This method was most commonly used to assess local knowledge and perceptions, often the primary reason for engaging with stakeholders (see Table 2). Questionnaires may improve scientific knowledge and help to guide policy formulation and management, but their ability to promote social learning, induce behavioural change, or increase transdisciplinary collaboration is normally very limited (Reed, 2008). A smaller number of case studies involved more deliberative or co-productive approaches, such as keyinformant interviews and closed-forum workshops or focus groups (20\%, Table 3). Many case studies (21\%) applied multiple engagement methodologies, including consultative and more

Table 2

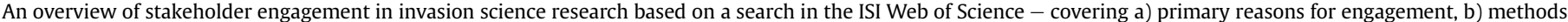

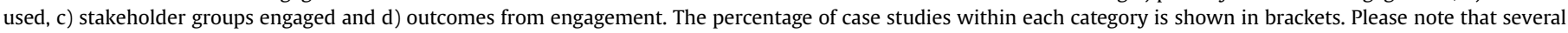

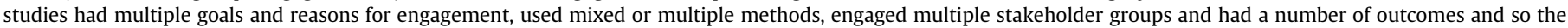
factors can add up to more than $100 \%$.

\begin{tabular}{|c|c|c|c|}
\hline \multicolumn{4}{|l|}{ Stakeholder engagement in managing biological invasions } \\
\hline Reasons & Methods \& approaches & Groups & Outcomes \& benefits \\
\hline $\begin{array}{l}\text { - Assessing knowledge \& perceptions of IAS (67\%) } \\
\text { - Improve scientific understanding (66\%) } \\
\text { - Informing policy \& management planning ( } 41 \%) \\
\text { - Taking part in collaborative research, management \& } \\
\text { citizen science (volunteers) ( } 23 \%) \\
\text { - Facilitating implementation of management decisions } \\
\text { ( } 17 \%) \\
\text { - Building cohesion \& consensus ( } 11 \%) \\
\text { - Reducing/resolving conflict ( } 7 \%) \\
\text { - Understanding the effects of IAS on stakeholders ( } 7 \%) \\
\text { - Awareness \& education }(7 \%) \\
\text { - Building collaborative projects ( } 6 \%) \\
\text { - Fulfilling policy mandates }(4 \%) \\
\text { - Behavioural change ( } 1 \%)\end{array}$ & $\begin{array}{l}\text { - Questionnaires (61\%) } \\
\text { - Key informant interviews } \\
\text { ( } 25 \% \text { ) } \\
\text { - Closed workshops/focus } \\
\text { groups (20\%) } \\
\text { - Open fora workshops/ } \\
\text { focus groups (6\%) } \\
\text { - Field visits/walks (5\%) } \\
\text { - Multi-criteria decision- } \\
\text { - } \text { making analysis ( } 3 \%) \\
\text { Participatory mapping } \\
\text { - Scenario planning ( } 1 \%) \\
\text { - Discourse analysis (1\%) }\end{array}$ & $\begin{array}{l}\text { - General public (51\%) } \\
\text { - Specific groups within the } \\
\text { general public ( } 34 \%) \\
\text { - Managers \& policy makers } \\
\text { ( } 23 \%) \\
\text { - Government institutions } \\
\text { - } 18 \%) \\
\text { - Academics/researchers } \\
\text { ( } 17 \%) \\
\text { - Conservation agencies ( } 14 \%) \\
\text { - Media }(9 \%) \\
\text { - NGO's }(9 \%) \\
\text { - Private business/industry } \\
\text { ( } 9 \%) \\
\text { - Volunteers (3\%) }\end{array}$ & 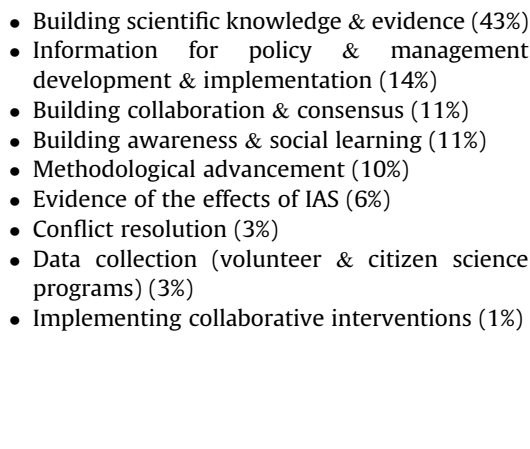 \\
\hline
\end{tabular}




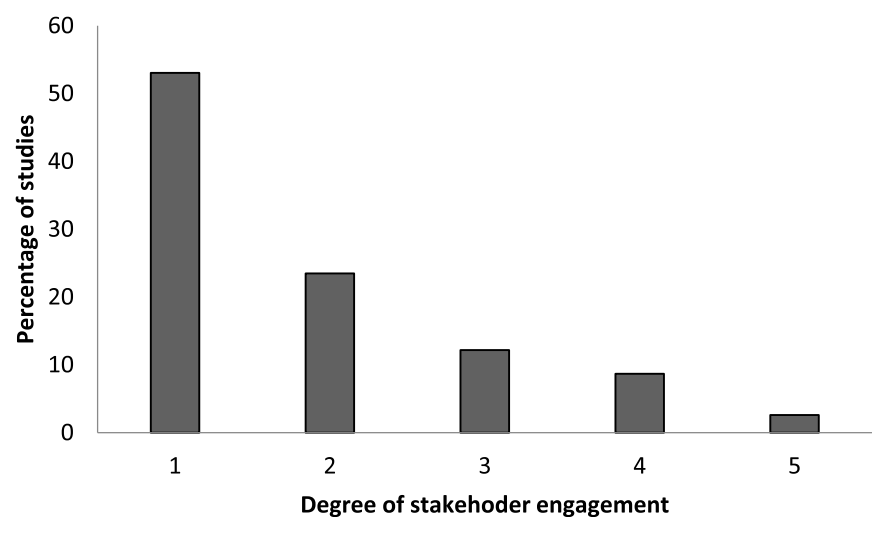

Fig. 4. The level of stakeholder engagement in case studies as scored by the expert reviewers. A score of 1 means passive engagement (one-way communication) with one or two groups. A score of 5 indicates active engagement (two-way communication) with five or more different stakeholder groups. The other factors $(2,3$, and 4$)$ are varying degrees of engagement in-between (i.e. different combinations of passive engagement with a number of stakeholder groups or active engagement with very few groups, see Appendix 1 for more detail).

deliberative and co-productive methods in the same study. More integrative and social science type approaches (e.g. multi-criteria decision making or scenario planning) were less often applied ( $<10 \%$ of case studies, Table 2 ) (e.g. Liu et al., 2011). This could have to do with the aims for engagement but also reflects the fact that much of this work was driven by ecologists - which is similar to other social-ecological and environmental management-related studies (Turner et al., 2016a; Vaz et al., 2017b; Abrahams et al., 2019). Only $1 \%$ of the studies primarily engaged stakeholders in unilateral communication with only a one-way flow of information from the organising/initiating stakeholder to other stakeholder groups (e.g. Cottet et al., 2015).

\subsubsection{Stakeholder groups engaged}

Most case studies (63\%) targeted only one specific stakeholder group. However, we also found studies which engaged multiple stakeholders (more than five); the highest number of stakeholders considered in a single study was 13 (see Bryce et al., 2011; Friedel et al., 2011; De Lange et al., 2012; Sharp, 2014). In general, the most commonly engaged stakeholder group was the general public, either via randomised samples (51\%) or targeting specific groups, for example, animal lovers (Barr et al., 2002) or school children (Reis et al., 2011). This focus on the public reflects the most common reason for engagement (Table 2), i.e. to assess people's general knowledge and perceptions. Other groups that were commonly engaged were land and conservation managers and policy makers, government departments and institutions, researchers and conservation groups (Table 2). To a lesser extent, the media, NGO's, private business and volunteers were also engaged.

\subsubsection{Stakeholder perceptions of invasive species}

A number of social and ecological factors influence whether a person or group of people have negative, positive or ambivalent

Table 3

The stance of different stakeholders towards invasive species management.

\begin{tabular}{ll}
\hline Stakeholder stance & \% of case studies \\
\hline Against & 47 \\
In favour of & 11 \\
Mixed feelings (both for and against) & 33 \\
Unsure/unknown & 9 \\
\hline
\end{tabular}

perceptions towards invasive alien species - which can also change over time (see Shackleton et al., 2018a; Udo et al. 2019). Almost half of the stakeholders engaged in the case studies were opposed to invasive species management (47\%). However, a large number of stakeholders had mixed perceptions of the invasive alien species(s) in question, with some groups and individuals in favour of and others against management (Table 3 ). This reflects the finding that in most cases, invasive species are perceived as having both benefits and costs (Fig. 3), as seen with many of the species in the top10 list (Table 1) which have both economic and/or intrinsic benefits and costs (Estévez et al., 2015; Olszańska et al., 2016; Novoa et al., 2016). The support for management is often more closely related to the level of impact of the target species than to its non-native status (van der Wal et al., 2015). The control method is also a strong factor determining support for management programmes, especially with invasive vertebrate species (Estévez et al., 2015; Olszańska et al., 2016). For example, through engagement studies it was found that the general public is less likely to support the management of invasive animals than that of invasive plants (Novoa et al., 2017). Furthermore, people generally show stronger support for managing invasive animals when non-lethal techniques such as post-fertilisation intervention, live trapping or contraceptive methods are used rather than lethal control methods such as hunting, trapping or poisoning (Olszańska et al., 2016). Hence, alternative strategies to killing animals often need to be considered in management programmes to increase public support, and engagement is crucial to find these solutions (Adriaens et al., 2015b; Vane and Runhaar, 2016).

\subsubsection{An evaluation of the degree of stakeholder engagement}

Based on the information provided in the assessed papers, the majority of the case studies showed fairly low levels of engagement with most including passive interaction with one or two stakeholder groups $(53 \%)$ or passive engagement with more than two groups (24\%, Fig. 4; see Appendix 1 for detailed description of levels of engagement). This is not surprising when considering that the main goal of most research was to assess knowledge and perceptions (Table 2), which is important to develop policy and management strategies (Shackleton et al., 2018a). Only 3\% of the studies showed high levels of engagement (i.e., active engagement with more than five stakeholder groups). Bryce et al. (2011) studied the eradication of American mink (Neovison vison) in and around a national park in Scotland. The programme involved co-funding by multiple stakeholders, strong collaborative social learning, coimplementation and a large number of different stakeholders (scientists, private property game keepers, public volunteers, various levels of fisheries staff, wildlife conservation professionals from government and NGOs, as well as land managers and landowners). This arrangement helped to give multiple stakeholders ownership in the project, which resulted in co-design, social learning and long-term collaboration on management implementation. This increased the overall success of the eradication program.

\subsubsection{Benefits engagement with stakeholders}

The most mentioned benefit of engagement in the reviewed papers was improving scientific knowledge (43\%), but a number of studies also directly provided information needed for policy and management implementation (14\%, Table 2$)$. In some studies, the engagement process was useful for building collaboration and consensus among different stakeholders (11\%) (e.g. Novoa et al., 2016), for promoting awareness and social learning (11\%) (e.g. Reis et al., 2011) or for advancing and adapting management methods (e.g. Cottet et al., 2015). 
3.5.7. Issues (problem areas/areas for improvement) of stakeholder engagement and research in invasion science

For each paper, we identified a number of potential improvements with respect to stakeholder engagement (Table 4). The majority of these related to the methodological limitation of engaging a small number of stakeholders, which introduced the potential for bias (39\%, Table 4). Many of the reviewed studies engaged with only one stakeholder group, but given the high proportion of case studies where feelings towards the species were mixed (both in favour and against) or unknown, this restricted representation can be problematic (Table 3 ). Although engagement with one group might answer specific questions, more integrative involvement could help to build consensus and social learning which could have more long-term benefits (see below). Therefore, the inclusion of different stakeholder groups may improve the usefulness of the work and help to give more insight and triangulate results (Bryman, 2004). Indeed, Tassin and Kull (2015) argue that it is common for invasion science to present a one-sided story based on negative impacts from a biological perspective that ignores benefits and perspectives based on cultural and other factors. From a more scientific writing and analysis perspective, it was worrying that a large number of studies gave little or no background information on the invasive species or on the stakeholder groups engaged. A crucial part of engaging stakeholders is to report-back findings to them and to promote social learning amongst them. This step was lacking or was not clearly elaborated in most of the studies reviewed. This is likely an issue for most studies since they were conducting only one-way consultations extracting information from participants without - in many instances - providing learning or any feedback. There are also growing concerns about stakeholder fatigue or overengagement and loss of interest (e.g. Blanchard, 2015; Turner et al., 2016a; b), as a small number of the studies in our sample faced issues of unwillingness of stakeholders to engage with researchers, which made research and information collection difficult (Table 4).

\section{Future needs for stakeholder engagement in research and management of invasive alien species}

There is clearly a trend towards increased emphasis on stakeholder engagement in the invasion literature (Fig. 1). Work in this direction has substantially increased our understanding of stakeholder motivations, aided policy formulation and management interventions, and has to a lesser extent also promoted collaboration and social learning (Tables 2 and 4). Several issues still need to be addressed to further improve the value of stakeholder engagement studies in the field of invasion science (Fig. 4 and Table 4). Our findings echo those of Manetti (2011) who emphasized that most stakeholder engagement was more about learning from and controlling stakeholders than about improving collaborations. In some biodiversity conservation projects it appears that stakeholder engagement was often included as an afterthought rather than being fully integrated into the project from the outset ( $c f$. Jolibert and Wesselink, 2012). The next section discusses four themes/ topics that deserve attention to ensure a better integration of stakeholder engagement in invasion research, thereby contributing to more effective management of invasive species.

\subsection{Improving the co-design, co-production and co-implementation of decision making and management actions}

In most of the case studies reviewed in this paper, the engagement process consisted of collecting information on the knowledge and perceptions of target stakeholders. This information can guide management decisions and foster further engagement (Shackleton et al., 2018a). However, stakeholders were primarily passive participants in the research, providing information but not being involved in much more, and certainly not in decision making or management implementation. Similarly, Jolibert and Wesselink (2012) analysed 38 EU-funded biodiversity research projects and found that stakeholders were not engaged during the critical stage of research development but were involved in the research dissemination stages, again very much as an after-thought. Reed et al. (2017) suggested that this level of engagement may be appropriate for certain purposes and contexts - i.e. if projects or decisions are already finalised as they possibly needed to be made quickly, but stakeholders need to be made aware of these decisions or outcomes then - which may be necessary for early detection and rapid response strategies targeting emerging invasive alien species. However, if the purpose is to engage stakeholders actively in the management of invasive species, to evaluate various management options, to resolve conflicts over the costs and benefits of invasive species and their management, or to change attitudes towards management, then deeper, two-way, co-productive engagement (possibly over long time-scales) is necessary (Mauser et al., 2013; Reed et al., 2017; Novoa et al., 2016, 2018). Different perspectives and approaches including top-down and bottom-up thinking also needs to be considered (Kull et al. 2019) as well as different knowledge systems (Bach et al., 2019; Kull et al., 2019; Udo et al., 2019). This is especially important as many invasive species provide both economic and intrinsic benefits and costs (Fig. 3, Table 3) which often greatly complicates the implementation of management initiatives (Woodford et al., 2016), especially when some stakeholders experience more benefits than costs or vice versa. Deeper or more protracted engagement is also warranted where invasive species occur across multiple land tenures or land-use settings (Bryce et al., 2011; Shackleton et al., 2015). These conditions call for co-design or co-development of projects, co-creation of knowledge, and co-implementation of management.

Co-production broadly refers to an approach involving designing research, producing knowledge, implementing decisions and management in collaboration with stakeholders from the outset (Sterling et al., 2017). Co-producing research outcomes that are jointly owned by all stakeholders can significantly increase the likelihood that findings are translated into practice and will be

Table 4

Problems (framed as areas of improvement), regarding stakeholder engagement in invasion science, based on the papers reviewed.

\begin{tabular}{lc}
\hline Problems/areas for improvement regarding engagement and outcomes & \% of case studies \\
\hline Improve methodology and scientific reporting & 39 \\
More perspectives or groups need to be represented & 19 \\
More collaborative approaches need to be used & 18 \\
Provide feedback and benefits back to stakeholders & 11 \\
Not just focus on research but also implementation and uptake & 7 \\
Build more towards conflict resolution & 4 \\
Tackle issues with stakeholders' willingness for engagement & 2 \\
\hline
\end{tabular}


sustained (de Vente et al., 2016; Shrestha et al., 2019). It can also help to build trust between stakeholders which may mitigate potential conflicts and improve collaboration, especially for species with both benefits and costs or those that invade across multiple land tenures (Reed et al., 2017; Wald et al., 2019). For example, the engagement described by Bryce et al. (2011) improved the management of invasive American mink in an area of Scotland through the co-funding, co-design and co-implementation of management actions with a number of stakeholder groups. It is, however, important to ensure that systematic methods are used for identifying all relevant stakeholders (e.g. Reed et al. (2009) reviewed the available methods for stakeholder analysis, Reed and Curzon (2015) developed a new matrix to do stakeholder analysis, and, Novoa et al. (2018) outlined specific processes for engagement relating to conflictd of interest around managing invasive alien species), as there is substantial evidence that poor stakeholder representation can lead to biased or unintended negative outcomes (de Vente et al., 2016; Sterling et al., 2017). Novoa et al. (2018) designed a step-by-step template for stakeholder engagement which aims to avoid or reduce conflicts of interests surrounding invasive species. Effective leadership is key for the co-production of the management actions and a champion is crucial to the project's success (Sterling et al., 2017), as is trust (Wald et al. 2019). Champions have a long-term interest in a project and are able to bring stakeholders together to work effectively towards a set of common targets or goals. This has been observed in a number of social-ecological systems and invasive species management programs (Turner et al., 2016a) and in citizen science and community-based environmental monitoring (e.g. Conrad and Hilchey, 2011; Pages et al., 2019).

\subsection{Promoting social learning and providing feedback to stakeholders}

Social learning is increasingly becoming a normative goal for environmental management and policy making (Reed et al., 2010). It should result in a change in the knowledge and perceptions of individuals involved in the engagement process. Building on the involved individuals' social capital, this information should then reach the broader public or other stakeholders through social interaction and processes. In particular, we suggest that engagement leading to social learning for the general public will have the greatest benefit for future management of invasive species (Reis et al., 2011; Adriaens et al., 2015a; Pagès et al., 2019). Promoting social learning is important for managing biological invasions, especially in the prevention and early-detection phases but also in the impact reduction phases of management. Social learning in the case of invasive species can lead to increased awareness and literacy of issues pertaining to biological invasions which is crucial for tackling such a complex environmental issue (Mascia et al., 2003; Lucy et al., 2016). Furthermore, knowledge is often lacking where the lowest level of management normally takes place (i.e. someone choosing to buy a native rather than invasive species or to remove an invasive species from their garden) (Shackleton and Shackleton, 2016; Gaertner et al., 2017). Therefore, promoting this learning could promote management and beneficial decision-making at the smallest scale. Cole et al. (2019) highlight that targeted awareness campaigns have promoted social learning, whereby, boaters are now increasingly cleaning equipment to help prevent the accidental spread of freshwater invasive species. Similarly, developing voluntary codes of conduct is a key component of invasive species management and social learning is a crucial ingredient in such initiatives (Brundu and Richardson, 2016). Social learning through effective and purposeful engagement allowed stakeholders to reach consensus on the management of cactus species in South
Africa and helped to build trust between parties (Novoa et al., 2016).

Giving feedback from the research findings is important (especially to stakeholders that were engaged but also to the broader public), since this will help improve social learning and local awareness and to keep stakeholders interested in the topic. This can be done in many ways, including via presentations or reports, in short films or documentaries (https://goo.gl/NYNBpo), using social media platforms (https://goo.gl/mKprhG), or articles in the popular press (https://goo.gl/cu1TMT) - examples are based on engagements reported in Shackleton et al. $(2015,2016)$ (but also see Marchante et al. (2017) for similar examples). Regular newsletters (e.g. https://goo.gl/W82wxA) can also be useful to keep stakeholders engaged and informed. Similar to the issues related to a lack of learning and feedback in invasion science, a number of EU co-funded conservation projects missed opportunities to inform stakeholders and facilitate meaningful policy formulation, as there was a poor level of social learning and effort to provide feedback (Jolibert and Wesselink, 2012).

\subsection{Working towards collaboration and partnerships beyond the natural sciences and beyond academia}

The majority of reviewed case studies were initiated by biologists and were published in biological journals (with Biological Conservation publishing most of the papers included in this review) which is common in invasion science and broader environmental management in general (Jolibert and Wesselink, 2012; Turner et al., 2016a; Vaz et al., 2017b). In invasion science, the number of interdisciplinary studies are increasing substantially, but the majority of current research still focuses on ecological questions (92\%) rather than social and socio-ecological ones (Vaz et al., 2017b). In part, this reflects the roots of invasion science as a sub-discipline of ecology even though the need for engagement with stakeholders has long been recognised as a pre-requisite for tackling conservation issues such as biological invasions (Mascia et al., 2003).

Improving collaboration and engagement of different stakeholders and disciplines could result in the use of a wider range of more appropriate participatory methods. This could render findings from engagement more meaningful and lead to better implementation and policy (Kueffer, 2013; Keeler et al., 2017). Cash et al. (2003) argued that such an approach increases the likelihood of science being translated into action because knowledge becomes more relevant to decision makers. It also makes research more credible (authoritative and trusted) and legitimate (developed via a process that considers the values and perspectives of all actors) to both scientists and stakeholders. This seems even more important to counter increasing populist anti-science movements presenting "alternative facts" and biological invasion denialism and can help to build trust amongst different parties (Apitz et al., 2017; Reed et al., 2017; Russel and Blackburn, 2017; Ricciardi and Ryan, 2018).

One of the reasons why stakeholder engagement and social science is often able to deliver more relevant, credible and legitimate outcomes is through the appreciation of context. Stakeholder engagement and the social sciences can provide rich and valuable contextual insights that may be overlooked when attempting to infer generalizable lessons from statistical relationships in invasion science. Stakeholder engagement based on case studies can provide novel insights of international significance and interest, with appropriate caveats pertaining to their generalisability. For example, new theory and methods may be tested in case study contexts that can be further developed and applied across a wide range of other contexts; additionally, empirical findings from one context may, with appropriate investigation and consideration, be applied or adapted to other settings internationally. 
In response to calls for greater engagement beyond natural sciences and academia, Keeler et al. (2017) have called for a "new kind of science" in which stakeholders move beyond being passive recipients of knowledge or objects of study to become equal partners in the research process. This partnership, they argue, also needs to extend to disciplines beyond the natural sciences, including the social sciences, arts and humanities, to "expand the frontiers of traditional disciplines, leading to new insights". To achieve this, Keeler et al. (2017) re-imagine academic structures to encourage innovation, training researchers in methods to achieve impact from their work and providing funding and leadership that promotes partnership and incentivises collaboration across disciplines and beyond the academy. The complexity of invasive species management is, and has always been, greater than any single method or discipline can appreciate or tackle. Only if we are willing to work beyond the boundaries of traditionally defined disciplines and approaches, will we be able to push invasion science and practice towards new knowledge that can inform effective solutions (Kull et al., 2018).

Many engagement projects driven by NGOs, some scientists and the governmental sector are not documented in a publicly accessible manner. Scientists and journalists should work towards connecting with stakeholders on these ongoing projects and documenting them in a way that they can be archived and easily accessed later. This would provide a database of case studies of indepth, on the ground engagement from which we can learn. The global initiative INVASIVESNET (Lucy et al., 2016; www. invasivesnet.org/) acknowledges the need for greater coordination, co-operation, and information exchange among stakeholders. It aims at increased interactions between scientists, managers, citizens and other stakeholders and introduces the vision of a reinforced global community of practice (sensu Wenger, 1998) on biological invasions.

A number of challenges related to social-ecological systems research and collaborative environmental management projects can arise (see Turner et al., 2016a; Bennett et al., 2017a, b). These include integrating and understanding different knowledge and ideological systems, accounting for change, funding and capacity, communication, facilitation and other factors (Turner et al., 2016a, b; Bennett et al., 2017a, b). However, identifying and understanding these issues early can help to overcome them through comprehensive planning and allowing room for adaptation and learning; the potential benefits of collaborative work are much greater than the challenges. Furthermore, with time and more integration many of these challenges should be overcome or become less prominent.

\subsection{Practical and policy suggestions for improving stakeholder engagement in invasion science and management}

International policy and regulations such as the Convention on Biological Diversity and the European Strategy on Invasive Alien Species, which underpins European Union regulations (Genovesi and Shine, 2004; Genovesi et al., 2015), explicitly acknowledge the critical need for stakeholder engagement in invasive species management and research. Although levels of stakeholder engagement are improving (Fig. 1), more must be done to expand and improve such engagements. Comprehensive stakeholder engagement should be a crucial facet of all management project proposals and most applied research proposals, and should be formally evaluated in the future.

There is growing evidence that stakeholder engagement processes lead to more beneficial environmental and social outcomes if they include: legitimate representation of stakeholders, professional facilitation including structured methods for aggregating information, balancing power dynamics among participants, and provision of information and decision-making power to all participants (Gregory et al., 2012; de Vente et al., 2016). For example, participative multi-criteria decision analysis can incorporate diverse interests in invasive species management (Liu et al., 2011). Structured decision making provides an effective methodological framework for exploring consensus solutions, based on wellinformed and transparent engagement (Estévez et al., 2013).

Two recently published frameworks provide practical, evidence-based guidance on how to engage stakeholders effectively in contentious decision-making processes, such as the management of invasive alien species (Reed, 2008; Novoa et al., 2018). Drawing on this work, it is essential that those seeking stakeholder engagement in invasive alien species management should; 1 ) investigate the local context in which engagement is sought to ensure that the most appropriate type of engagement (in terms of its mode e.g. communicative versus co-productive, and agency e.g. top-down versus bottom-up) is implemeted for the given purpose and context; 2) systematically represent the needs and priorities of as many affected parties as possible, using approaches such as stakeholder analysis to ensure legitimate representation early in the process; and 3) pay attention to power dynamics, using professional facilitation and structure elicitation techniques to ensure the knowledge and other inputs of all participants are valued and that all stakeholder groups are given opportunities to contribute.

\section{Acknowledgements}

RTS, AN and DMR acknowledges funding from the DST-NRF Centre of Excellence for Invasion Biology $(C \cdot I \cdot B)$ and RTS acknowledges Stellenbosch University through "Consolidoc" funding of the office of the Vice Rector: Research, Innovation and Postgraduate Studies and a grant (to BL) from the Social Sciences and Humanities research Council of Canada (SSHRC) which helped to make this research possible. DMR received funding from the C.I.B and the National Research Foundation of South Africa (grant 85417). AN acknowledges funding from the Centre of Excellence PLADIAS (Czech Science Foundation Project No. 14-36079G) and the long-term research development project (The Czech Academy of Sciences, Project No. RVO 67985939) and South African National Department of Environment Affairs through its funding of the South African National Biodiversity Institute's Invasive Species Programme.

\section{Appendix 1. Data collection/extraction template}

\section{Stakeholder review paper - literature review guidelines}

Aims: The broad aims of this paper are to get a better understanding of reasons for engagement of stakeholders within invasive species research and management, to assess what methods have been used and identify the outcomes of such engagements (both successes and failures). This will enable us to identify gaps and provide recommendation to improve engagement in the future.

Definition of "stakeholder" for this review. In this review we will define stakeholders as any group/or individual that is engaged or participates in the process for the purpose of studying and/or managing invasive species and is either directly or indirectly benefited or negatively impacted by, or involved with invasive species and/or their management. We take on a very broad view of stakeholder engagement which includes active (hands on engagement where stakeholders contribute actively) and passive engagement (information provision by stakeholder/participation in a questionnaire).

Definition of "invasive species". In this paper invasive species 
are defined according to Blackburn et al. (2011). These are species that have been moved by humans into new locations away from their native ranges, have survived and naturalised and have started to spread naturally (become invasive).

\section{Section 1: paper information}

Colum A) Please list your initials.

Column B) List the case study author/authors. In papers with more than two authors, indicate only the first author and et al.,

Column C) List the date of publication.

Column D) List the name of the journal. If not a journal, list as book, book chapter, conference paper, presentation or other relevant category.

Column E) Please code the primary theme of the journal. Code as: ecology/biology focused (1); social science focused (2); policy and management focused (3); interdisciplinary focused (4); or other (5) and please specify. ${ }^{*}$ leave this question out if it is not a journal.

Section 2: background information on the invasive/s and where the work was done

Note If the information is not available indicate by inserting $\mathbf{n} / \mathbf{a}$ into the cell.

Also, to ensure that the data is accurate; if for any of the reviewed papers you are uncertain or have any doubts in the data you have extracted highlight the particular excel cell in red. It will then be reviewed and double checked.

Lastly, some papers may be included from the literature search that do not actually involve any active stakeholder engagement case studies. They might discuss stakeholder's points of view and issues surrounding stakeholder compliance etc. If this is the case, please just put the paper information in (section 1) and leave the rest of the data capture out.

Column F) List the country/countries where the work was done. In papers presenting studies in more than one country, indicate each country in a separate cell one below each other if it is less than 5. *If it is more than five countries list the continent or island group.

Colum G) List the continent the study took place in; Africa (1); Asia (2); Australasia (3); Europe (4); North America (5); South America (6); Island/island group (7). * If more than one list each number in the same cell.

Column H) List the scientific name of the studied species. For papers dealing with multiple species, list the species separately each in their own cell one below each other. Alternatively, if multiple species are researched, give the broad taxonomic group/ functional group (e.g. invasive trees, invasive grasses, invasive fish, invasive terrestrial vertebrates, marine invertebrates, etc).

Column I) List the functional group of the studied species. In papers dealing with multiple species, please, indicate the functional group of each of the species in separate cells below each other. Code as; Plants; trees (1); grasses (2); perennial shrubs (3); annual shrubs (4); vines (5) succulents and cacti (6); Animals terrestrial invertebrates (7) freshwater invertebrates (8) marine invertebrates (9); birds (10); amphibians (11); reptiles (12); freshwater fish (13); marine fish (14); land mammal (15); marine mammal (16); fungi/bacteria (17); other (18 - and please specify).

Column J) If possible please provide the pathway of introduction for the target invasive/s. ornamental (1); agricultural (2); forestry (3); agroforestry (4); aquiculture (5); pet trade (6); recreation (7); soil improvement (8); accidental (9); other (10 - please specify); unknown (11).

Column K) List the date of introduction (if it is indicated in the paper) of the case study invasive/s. A rough estimation would also be ok (e.g. approximately 1900). If the paper does not mention a date of introduction, indicate $n / a$. If there are several dates of introduction put the earliest date.

Column L) Categorise the level/area of invasion. Code as Localised sparse (1); localised abundant (2); regional sparse (3); regional/provincial abundant (4); national/provincial sparse (5); national abundant (6); international (7); or not mentioned or not clear in the paper (8).

Column M) Type of area invaded in the case study; Urban (1); Rural - (disturbed/modified e.g. farmlands etc); (2); Rural- (natural/ conservation); more than one of these categories (3 - and specify); other (4- please specify).

Column N) Please give an indication of the primary land tenure/ use in the case study. Code as: private rangeland/farmland (1); agricultural fields (2); communal rangeland/farmland (3), protected/natural/conservation areas (4); urban areas (5); multiple land tenures/uses (6); other ( 7 - please specify).

Column 0) Please categorise the biome/s covered in the case study. Code as: Aquatic - Freshwater (1); freshwater wetland (2); marine (3); coral reef (4), estuaries (5); Terrestrial - Tundra (6); rainforest (7); savanna (8); boreal or coniferous forest (9); temperate forest (10); grassland (11); alpine (12); Mediterranean (chaparral) (13); Desert (14); Multiple biomes (15); Other (16 please specify).

Column P) Please list the type of impacts of the invader listed in the paper. Code as: Biodiversity (1); Ecosystem services (if it covers and provisioning, regulating, supporting and cultural service) (2); human well-being (economic, intrinsic, health, etc) (3); two of these categories (4); three or more of there categories (5); no impacts mentioned (6)

Column Q) Please list the benefits of the invader in the paper. Code as: Biodiversity (1); ecosystem services (if it covers and provisioning, regulating, supporting and cultural service) (2); human well-being (economic; intrinsic, etc) (3); two of categories (4); three or more of these categories (5); no benefits mentioned (6).

\section{Section 3: stakeholder engagement information}

Column R) At what scale did participation take place; Code as: local (1); regional/provincial (2); national (3); international (4); Island territory (5); other (please, specify) (6); not mention or unclear (7).

Column S) Reason for engagement. Code as: policy and management planning (1); information gathering (2); citizen science (3); building cohesion and consensus (4); to fulfil policy mandates (5); conflict resolution (6); building collaborations (7); assessing perceptions (8); facilitating management implementation (9); setting up projects (10); research (11); improving understanding/ knowledge production (13); multiple reasons (and include all the numbers separated by a comma in one cell); other (14 - and please specify).

Column T) Engagement method. Please list the method/ methods of engagement. Questionnaires (1); open form workshops (anyone can attend) (2); closed workshops/invited guests only (3); key informant interviews (4); scenario planning workshops (4); multi-criteria decision making analysis (5); participatory mapping (6); field visits (7); multiple reasons (and include all the numbers separated by a comma in one cell); other ( 8 - please specify).

Column U) Categorise the information flow; Code as: Communication (1); consultation (2); collaboration/dialogue (3); or other (4) and specify. ${ }^{*}$ Communication is the one-way information flow from the initiator/organiser to the public/other institutions. Consultation is the one-way flow from the public/institution to the initiator/organiser. Collaboration/dialogue is the flow of information between multiple parties. 
Column V) Insert the total number of different stakeholder' groups engaged - (the sum of the previous column).

Column W) Number of people engaged if given. Please, if possible, list the total number of people engaged (sample size) in the study. E.g. 50 workshop participants, 200 questionnaires or 250 participants (between workshop and questionnaires)). Or code it as: $1-10$ people (1); $11-30$ people (2); $31-50$ people (3); $51-70$ people (4); 71-100 people (5); 101-150 people (6); 151-200 people (7); 201-250 people (8); 251-300 people (9); greater than 300 people (10).

Column X) Please, list all the stakeholder' groups engaged in the paper. Code as: managers and policy makers (1); researchers (2); the general/random people from public (3); specific groups or audiences in the public (please specify) (4) media (5); government institutions/departments (6); conservation agencies (5); NGO's (7); private businesses (please specify) (8); other ( 9 - please identify) *If multiple stakeholders are mentioned/engaged, indicate each one in a separate cell, one below each other.

Column Y) For each stakeholder group identify the influence of the invasive species. Code as: beneficial (1); negative impacts (2); both beneficial and costly (negative impacts) at the same time (3); no impact (4); or unknown/irrelevant (5).

Column Z) In the case study please categorise each stakeholders as being - Code as: Pro (1); against (2); neutral (3); unknown/ irrelevant (4).

Column AA) Are conflicts of interest surrounding the invasive species mentioned in the case study article; Code as: Yes (1); no (2).

Colum BB) If stated, did engagement change perceptions, behaviour or practices of the stakeholders. Code as: Yes (1); no (2).

Column (C). What was the outcome of the engagement if done for conflict resolution? Code as: intensify conflict (1); reduce conflict (2); resolve conflict (3); other (4). This is only relevant for studies that answer (Yes/1) in column $\mathrm{W}$.

Column DD) If the cost of the engagement method is give please put it in US\$.

Section 4: scientific evaluation of the paper by the case study reviewer

Column EE) Please rate the overall degree of stakeholder engagement in the case study: Code from 1 to 5 ( 1 - being low and 5 being high). ${ }^{*}$ Low engagement will involve only passive interaction with one or two specific groups. A rank of high engagement will be active engagement with a multitude of different stakeholders. 1: passive engagement, including 1-2 stakeholder groups 2: passive engagement including $>2$ stakeholder groups 3: active engagement, including 1-2 stakeholder groups 4: active engagement including $>2$ stakeholder groups 5: active engagement including $>5$ stakeholder groups.

Column FF) Was engagement effective for the study, code as Yes (1), no (2) or other (3 - and specify).

Column GG) Please indicate if you think that in this case study the engagement of stakeholders was (code as) beneficial = (1); or unbeneficial (2); other (3) - and specify.

Column HH) If beneficial - describe why in one line. * skip if unbeneficial.

Column II) If unbeneficial - describe why in one line.

Column JJ) Is this study worth repeating, code as; Yes (1); no (2); other ( 3 - and specify).

Column KK) Please describe one really good/successful aspect of the engagement described in this paper this paper.

Column LL) Please describe one aspect or challenge that could be improved of the engagement described in this paper, either identified by the authors or by you. any.

Column MM) Add any interesting notes/comments - if there are

\section{References}

Abrahams, B., Sitas, N., Elser, K.J., 2019. Exploring the dynamics of research collaborations by mapping social networks in invasion science. J. Environ. Manage. 229, 27-37. https://doi.org/10.1016/j.jenvman.2018.06.051.

Adriaens, T., Sutton-Croft, M., Owen, K., Brosens, D., van Valkenburg, J., Kilbey, D. Groom, Q., Ehmig, C., Thürkow, F., Van Hende, P., Schneider, K., 2015a. Trying to engage the crowd in recording invasive alien species in Europe: experiences from two smartphone applications in northwest Europe. Manage. Biol. Invasions 6, 215-225.

Adriaens, T., Baert, K., Breyne, P., Casaer, J., Devisscher, S., Onkelinx, T., Pieters, S., Stuyck, J., 2015b. Successful eradication of a suburban Pallas's squirrel Callosciurus erythraeus (Pallas 1779) (Rodentia, Sciuridae) population in Flanders (northern Belgium). Biol. Invasions 17, 2517-2526.

Apitz, S.E., Backhaus, T., Chapman, P.M., Landis, W., Suter, G., 2017. Science, antiscience, and environmental decision making: a call to action. Integ. Environ. Assess 13, 557-559.

Bach, T.M., Kull, C.A., Rangan, H., 2019. From killing lists to healthy country: aboriginal approaches to weed control in the Kimberley, Western Australia. J. Environ. Manamge. 229, 182-192. https://doi.org/10.1016/j.jenvman.2018.06. 050.

Barr, J.J.F., Lurz, P.W.W., Shirley, M.D.F., Rushton, S.P., 2002. Evaluation of immunocontraception as a publicly acceptable form of vertebrate pest species control: the introduced grey squirrel in Britain as an example. Environ. Manage 20, $342-351$.

Bennett, N.J., Roth, R., Klain, S.C., Chan, K., Christie, P., Clark, D.A., Cullman, G., Curran, D., Durbin, T.J., Epstein, G., Greenberg, A., Nelson, M.P., Sandlos, J., Stedman, R., Teel, T.L., Thomas, R., Veríssimo, D., Wyborn, C., 2017a. Conservation social science: understanding and integrating human dimensions to improve conservation. Biol. Conserv. 205, 93-108.

Bennett, N.J., Roth, R., Klain, S.C., Chan, K., Clark, D.A., Cullman, G., Epstein, G., Nelson, M.P., Stedman, R., Teel, T.L., Thomas, R.E.W., Wyborn, C., Currn, D., Greenberg, A., Sandlos, J., Veríssimo, D., 2017b. Mainstreaming the social sciences in conservation. Conserv. Biol. 31, 56-66.

Binimelis, R., Monterroso, I., Rodríguez-Labajos, B., 2007. A social analysis of the bioinvasion of Dreissena polymorpha in Spain and Hydrilla verticillata in Guatemala. Environ. Manage 40, 555-566.

Blanchard, A., 2015. Choosing our food futures through participation? A critique of 'Scenario Workshops' in Lofoten. In: Food Security and Food Safety for the Twenty-first Century. Springer, Singapore, pp. 217-227.

Bravo-Vargas, V., García, R.A., Pizarro, C., Pauchard, A., 2019. Do people care about pine invasions? Visitor perceptions and willingness to pay for pine control in a protected area. J. Environ. Manage. 229, 57-66.

Bremner, A., Park, K., 2007. Public attitudes to the management of invasive nonnative species in Scotland. Biol. Conserv. 139, 306-314.

Brundu, G., Richardson, D.M., 2016. Planted forests and invasive alien trees in Europe: a Code for managing existing and future plantings to mitigate the risk of negative impacts from invasions. Neobiota 30, 5-47.

Bryce, R., Oliver, M.K., Davies, L., Gry, H., Urquhart, J., Lambin, X., 2011. Turning back the tide of American mink invasion at an unprecedented scale trough community participation and adaptive management. Biol. Conserv. 144, 575-583.

Bryman, A 2004. Triangulation. In: Lewis-Beck, M.S, Bryman, A Futing Liao, T. (Eds.), Encyclopaedia of Social Science Research Methods. SAGE Publications, Inc, Thousand Oaks, CA, pp. 1143-1144.

Buchadas, A., Vaz, A.S., Honrado, J.P., Alagador, D., Bastos, R., Cabral, J.A., Santos, M., Vicente, J.R., 2017. Dynamic models in research and management of biological invasions. J. Environ. Manage 196, 594-606.

Cash, D.W., Clark, W.C., Alcock, F., Dickson, N.M., Eckley, N., Guston, D.H., Jäger, J., Mitchell, R.B., 2003. Knowledge systems for sustainable development. PNAS 100, 8086-8091.

Cole, E., Keller, R.P., Garbach, K., 2019. Risk of invasive species spread by recreational boaters remains high despite widespread adoption of conservation behaviours. J. Environ. Manage. 229, 112-119. https://doi.org/10.1016/j.jenvman.2018.06. 078

Cole, E., Keller, R.P., Garbach, K., 2016. Assessing the success of invasive species prevention efforts at changing the behaviors of recreational boaters. J. Environ. Manage 184, 210-218.

Colton, T.F., Alpert, P., 1998. Lack of public awareness of biological invasion by plants. Nat. Areas J. 18, 262-266.

Cottet, M., Piola, F., Le Lay, Y.F., Rouifed, S., Rivière-Honegger, A., 2015. How environmental managers perceive and approach the issue of invasive species: the case of Japanese knotweed s.l. (Rhône River, France). Biol. Invasions 17, $433-3453$.

Dawson, W., Moser, D., van Kleunen, M., Kreft, H., Pergl, J., Pyšek, P., Weigelt, P., Winter, M., Lenzner, B., Blackburn, T.M., Dyer, E.E., Cassey, P., Scrivens, S.L., Economo, E.P., Guénard, B., Capinha, C., Seebens, H., García-Díaz, P., Nentwig, W., García-Berthou, E., Casal, C., Mandrak, N.E., Fuller, P., Meyer, C., Essl, F., 2017. Global hotspots and correlates of alien species richness across taxonomic groups. Nat. Ecol. Evol. 1, 0186. 
de Vente, J., Reed, M., Stringer, L., Valente, S., Newig, J., 2016. How does the context and design of participatory decision making processes affect their outcomes? Evidence from sustainable land management in global drylands. Ecol. Soc. 21, 24.

Dehnen-Schmutz, K., Chas-Amil, M.L., Touza, J., 2010. Stakeholders' perceptions of plant invasions in Galicia. Spain. Asp. Appl. Biol. 104, 13-18.

De Lange, W.J., Stafford, W.H.L., Forsyth, G.G., Le Maitre, D.C., 2012. Incorporating stakeholder preferences in the selection of technologies for using invasive alien plants as a bio-energy feedstock: Applying the analytical hierarchy process. J. Environ. Manage. 99, 76-83.

Estévez, R.A., Walshe, T., Burgman, M.A., 2013. Capturing social impacts for decision-making: a Multicriteria Decision Analysis perspective. Divers. Distrib. 19, 608-616.

Estévez, R.A., Anderson, C.B., Pizarro, J.C., Burgman, M.A., 2015. Clarifying values, risk perceptions and attitudes to resolve or avoid social conflicts in invasive species management. Conserv. Biol. 29, 19-30.

Falagas, M.E., Pitsouni, E.I., Malietzis, G.A., Pappas, G., 2008. Comparison of PubMed, Scopus, web of science, and Google scholar: strengths and weaknesses. FASEB J. 22, 338-342.

Finch, N.A., Baxter, G.S., 2007. Oh deer, what can the matter be? Landholder attitudes to deer management in Queensland. Wildl. Res. 34, 211-217.

Fischer, A., Selge, S., van der Wal, R., Larson, B.W.H., 2014. The public and professionals reason similarly about the management of non-native invasive species. A quantitative investigation of the relationship between beliefs and attitudes. PLOS ONE 9, e105495.

Forsyth, G.G., Le Maitre, D.C., O'Farrell, P.J., van Wilgen, B.W., 2012. The prioritisation of invasive alien plant control projects using a multi-criteria decision model informed by stakeholder input and spatial data. J. Environ. Manage 103, 51-57.

Foxcroft, L.C., Pyšek, P., Richardson, D.M., Genovesi, P., McFadden, S., 2017. Plant invasions in protected areas: progress and priorities. Biol. Invasions 19, 1353-1378.

Freeman, R.E., 1984. Strategic Management: a Stakeholder Approach. Basic Books, New York.

Friedel, M.H., Grice, A.C., Marshall, N.A., van Klinken, R.D., 2011. Reducing contention amounts organisations dealing with commercially valuable but invasive pants: the case of buffel grass. Environ. Sci. Pol. 14, 1205-1218.

Friedman, A., Miles, S., 2006. Stakeholders: Theory and Practice. Oxford University Press, Oxford.

Gaertner, M., Larson, B.M.H., Irlich, U.M., Holmes, P.M., Stafford, L., van Wilgen, B.W., Richardson, D.M., 2016. Managing invasive species in cities: a framework from Cape Town, South Africa. Landsc. Urban Plan. 151, 1-9.

Gaertner, M., Novoa, A., Fried, J., Richardson, D.M., 2017. Managing invasive species in cities: a decision support framework applied to Cape Town. Biol. Invasions 19, 3461-3469.

García-Llorente, M., Martín-López, B., González, J.A., Alcorlo, P., Montes, C., 2008. Social perceptions of the impacts and benefits of invasive alien species: implications for management. Biol. Conserv. 141, 2969-2983.

Genovesi, P., Shine, C., 2004. European Strategy on Invasive Alien Species: Convention on the Conservation of European Wildlife and Habitats (Bern Convention) (No. 18-137). Council of Europe.

Genovesi, P., Carboneras, C., Vila, M., Walton, P., 2015. EU adopts innovative legislation on invasive species: a step towards a global response to biological invasions? Biol. Invasions 17, 1307-1311.

Gregory, R., Failing, L., Harstone, M., Long, G., McDaniels, T., Ohlson, D., 2012. Structured Decision Making: a Practical Guide to Environmental Management Choices. Wiley, New York.

Halford, M., Heemers, L., van Wesemael, D., Mathys, C., Wallens, S., Branquart, E., Vanderhoeven, S., Monty, A., Mahy, G., 2014. The voluntary Code of conduct on invasive alien plants in Belgium: results and lessons learned from the AlterIAS LIFE + project. EPPO B 44, 212-222.

Higgins, J.P.T., Green, S., 2011. Cochrane handbook for Systematic Reviews of Interventions. The Cochrane Collaboration, 5.1.0.

Hilty, J., Merenlender, A.M., 2003. Studying biodiversity on private lands. Conserv. Biol. 17, 132-137.

Hui, C., Richardson, D.M., 2017. Invasion Dynamics, Oxford University Press, Oxford. Hulme, P.E., Pyšek, P., Pergl, J., Jarošík, V.., Schaffne, U., Vilá, M., 2014. Greater focus needed on alien plant impacts in protected areas. Conserv. Lett. 7, 459-46.

Jeschke, J.M., Bacher, S., Blackburn, T.M., Dick, J.T., Essl, F., Evans, T., Gaertner, M. Hulme, P.E., Kühn, I., Mrugała, A., Pergl, J., 2014. Defining the impact of nonnative species. Conserv. Biol. 28, 1188-1194.

Jolibert, C., Wesselik, A., 2012. Research impacts and impact on research in biodiversity conservation: the influence of stakeholder engagement. Environ. Sci. Policy 22, 100-111.

Kannan, R., Shackleton, C.M., Shaanker, R.U., 2014. Invasive alien species as drivers in socio-ecological systems: local adaptations towards use of Lantana in Southern India. Environ. Dev, Sus 16, 649-669.

Keeler, B.L., Chaplin-Kramer, R., Guerry, A.D., Addison, P.F., Bettigole, C., Burke, I.C., Gentry, B., Chambliss, L., Young, C., Travis, A.J., Darimont, C.T., 2017. Society is ready for a new kind of science-is academia? BioScience 67, 591-592.

Keen, M., Brown, V.A., Dyball, R., 2005. Social Learning in Environmental Management: towards a Sustainable Future. Routledge.

Kueffer, C., 2013. Transdisciplinary research is needed to predict plait invasion in an ear of global change. Trends Ecol. Evol. 25, 619-620.

Kull, C.A., Harimanana, S.L., Radaniela Andrianoro, A., Rajoelison, L.G., 2019. Divergent perceptions of the 'neo-Australian' forests of lowland eastern Madagascar: invasions, transitions, and livelihoods. J. Environ. Manage. 229, 48-56. https:// doi.org/10.1016/j.jenvman.2018.06.004.

Kull, C.A., Shackleton, C.M., Cunningham, P.S., Ducatillon, C., Dror, J.D., Esler, K.J., Friday, J.B., Gouveia, A.C., Griffin, A.R., Marchante, E., Midgley, S.J., Pauchard, A., Rangan, H., Richardson, D.M., Rinaudo, T., Tassin, J., Urgenson, L.S., Maltitz, G.P. Zenni, R.D., Zylstra, M.J., 2011. Adoption, use and perception of Australian acacias around the world. Divers. Distrib. 17, 822-836.

Kull, C.A., Kueffer, C., Richardson, D.M., Vaz, A.S., Vicente, J., Honrado, J.P., 2018. Using the 'regime shift' concept in addressing social-ecological change. Geogr. Res. 56, 26-41.

Larson, B.M.H., 2007. An alien approach to invasive species: objectivity and society in invasion biology. Biol. Invasions 9, 947-956.

Limburg, K.E., Luzadis, V.A., Ramsey, M., Schulz, K.L., Mayer, C.M., 2010. The good, the bad and the algae: perceiving ecosystem services and disservices generated by zebra and quagga mussels. J. Gt. Lakes. Res. 36, 86-92.

Liu, S., Proctor, W., Cook, D., 2010. Using an integrated fuzzy set and deliberative multi-criteria evaluation approach to facilitate decision-making in invasive species management. Ecol. Econ. 69, 2374-2382.

Liu, S., Sheppard, A., Kriticos, D., Cook, D., 2011. Incorporating uncertainty and social value in managing invasive alien species; a deliberative multi-criteria evaluation approach. Biol. Invasions 13, 2323-2337.

Lowry, E., Rollinson, E.J., Laybourn, A.J., Scott, T.E., Aiello-Lammens, M.E., Gray, S.M. Mickley, J., Gurevitch, J., 2013. Biological invasions: a field synopsis, systematic review, and database of the literature. Ecol. Evol. 3, 182-196.

Lucy, F.E., Roy, H., Simpson, A., Carlton, J.T., Hanson, J.M., Magellan, K. Campbell, M.L., Costello, M.J., Pagad, S., Hewitt, C.L., McDonald, J., Cassey, P., Thomaz, S.M., Katsanevakis, S., Zentos, A., Tricarico, E., Boggero, A., Groom, Q.J. Adriaens, T., Vanderhoeven, S., Torchin, M., Hufbauer, R., Fuller, P., Carman, M.R. Conn, D.B., Vitule, J.R.S., Canning-Clode, J., Galil, B.S., Ojaveer, H., Baily, S.A. Therriault, T.W., Claudi, R., Gazda, A., Dick, J.T.A., Caffrey, J., Witt, A., Kenis, M. Letiniemi, M., Helmisarri, H., Panov, V.E., 2016. INVASIVESNET towards an international association for open knowledge on invasive alien species. Manage. Biol. Invasions 7, 131-139.

Manetti, G., 2011. The quality of stakeholder engagement in sustainability reporting: empirical evidence and critical points. Corp. Soc. Resp. Env. Ma 18, $110-122$.

Marchante, H., Morais, M.C., Gamela, A., Marchante, E., 2017. Using a WebMapping platform to engage volunteers to collect data on invasive plants distribution. T. GIS 21, 238-252.

Mascia, M.B., Brosius, J.P., Dobson, T.A., Forbes, B.C., Horowitz, L., McKean, M.A. Turner, N.J., 2003. Conservation and the social sciences. Conserv. Biol. 17, 649-650.

Mauser, W., Klepper, G., Rice, M., Schmalzbauer, B.S., Hackmann, H., Leemans, E. Moore, H., 2013. Transdisciplinary global change research: the co-creation of knowledge for sustainability. Curr. Opin. Env. Sust. 5, 420-431.

McNeely, J.A. (Ed.), 2001. The Great Reshuffling: Human Dimensions of Invasive Alien Species. Gland: IUCN.

ME, Millennium Ecosystem Assessment. Millennium ecosystem assessment. Ecosystems and human wellbeing: a framework for assessment Island. Press: Washington, DC.

Monterroso, I., Binimelis, R., Rodríguez-Labajos, B., 2011. New methods for the analysis of invasion processes: multi-criteria evaluation of the invasion of Hydrilla verticillata in Guatemala. J. Environ. Manage 92, 494-507.

Mwangi, E., Swallow, B., 2008. Prosopis juliflora invasion and rural livelihoods in the Lake Baringo area of Kenya. Conserv. Soc. 6, 130-140.

Novoa, A., Kaplan, H., Kumschick, S., Wilson, J.R.U., Richardson, D.M., 2015. Soft touch or heavy hand? Legislative approaches for preventing invasions: insights from cacti in South Africa. Invasive Plant Sci. Manage 8, 307-316.

Novoa, A., Kaplan, H., Wilson, J.R.U., Richardson, D.M., 2016. Resolving a prickly situation: involving stakeholders in invasive cactus management in South Africa. Environ. Manage 57, 998-1008.

Novoa, A., Dehnen-Schmutz, K., Fried, J., Vimercati, G., 2017. Does public awareness increase support for invasive species management? Promising evidence across taxa and landscape types. Biol. Invasions 19, 3691-3705.

Novoa, A., Shackleton, R.T., Canavan, S., Cybéle, C., Davies, S., Dehnen-Schmutz, K., Fried, J., Gaertner, M., Geerts, S., Griffiths, C., Kaplan, H., Kumschick, S., Le Maitre, D.C., Measey, J., Nunes, A.L., Richardson, D.M., Robinson, T.B., Touza, J. Wilson, J.R.U., 2018. A framework for engaging stakeholders on the management of alien species. J. Environ. Manage 205, 286-297.

Nunez, M.A., Pauchard, A., 2010. Biological invasions in developing and developed countries: does one model fit all? Biol. Invasions 12, 707-714.

Olszańska, A., Solarz, W., Najberek, K., 2016. To kill or not to kill-practitioners' opinions on invasive alien species management as a step towards enhancing control of biological invasions. Environ. Sci. Policy 58, 107-116.

Ostrom, E., 2009. A general framework for analyzing sustainability of socialecological systems. Science 325, 419-422.

Pagès, M., Fischer, A., van der Wal, R., Lambin, X., 2019. Empowering communities or "cheap labour"? Engaging volunteers in the rationalised management of invasive alien species in Great Britain. J. Environ. Manage. 229, 102-111. https:// doi.org/10.1016/j.jenvman.2018.06.053.

Perry, D., Perry, G., 2008. Improving interaction between animal rights groups and conservation biologists. Conserv. Biol. 22, 27-35.

Potgieter, L., Gaertner, M., O'Farrell, P., Richardson, D.M., 2019. Perceptions of impact: invasive alien plants in the urban environment. J. Environ. Manage. 229, 76-87. https://doi.org/10.1016/j.jenvman.2018.05.080. 
Pyšek, P., Richardson, D.M., Rejmánek, M., Webster, G.L., Williamson, M., Kirschner, J., 2004. Alien plants in checklists and floras: towards better communication between taxonomists and ecologists. Taxon 53, 131-143.

Pyšek, P., Jarošík, V., Hulme, P.E., Pergl, J., Hejda, M., Schaffner, U., Vilà, M., 2012 A global assessment of invasive plant impacts on resident species, communities and ecosystems: the interaction of impact measures, invading species' traits and environment. Glob. Change Biol. 18, 1725-1737.

Reed, M.S., 2008. Stakeholder participation for environmental management: a literature review. Biol. Conserv. 141, 2417-2431.

Reed, M.S., Curzon, R., 2015. Stakeholder mapping for the governance of biosecurity: a literature review. J. Int. Environ. Sci. 12, 15-38.

Reed, M.S., Graves, A., Dandy, N., Posthumus, H., Huback, K., Morris, J., Prell, C., Quinn, C.H., Stringer, L.C., 2009. Who's in and why? A typology of stakeholder analysis methods for natural resource management. J. Environ. Manage 90, 1933-1949.

Reed, M.S., Evely, C., Cundill, G., Fazey, I., Laing, F.A., Newig, J., Parrish, B., Prell, C., Raymond, C., Stringer, L.C., 2010. What is social learning? Ecol. Soc. 15.

Reed, M.S., Vella, S., Sidoli del Ceno, J., Neumann, R.K., de Vente, J., Challier, S., Frewer, L., van Delden, 2017. A theory of participation: what makes stakeholde engagement and public engagement in environmental management work? Restor. Ecol. https://doi.org/10.1111/rec.12541.

Reis, C.S., Marchante, H., Freitas, H., Marchante, E., 2011. Public perception of invasive plant species: assessing the impact of workshop activities to promote young students awareness. Int. J. Sci. Educ. 35, 690-712.

Rejmánek, M., Richardson, D.M., 2013. Trees and shrubs as invasive alien species 2013 update of the global database. Divers. Distrib. 19, 1093-1094.

Ricciardi, A., Ryan, R., 2018. The exponential growth of invasive species denialism. Biol. Invasions. https://doi.org/10.1007/s10530-017-1561-7 (in press).

Ricciardi, A., Blackburn, T.M., Carlton, J.T., Dick, J.T., Hulme, P.E., Iacarella, J.C. Jeschke, J.M., Liebhold, A.M., Lockwood, J.L., MacIsaac, H.J., Pyšek, P., 2017. Invasion science: a horizon scan of emerging challenges and opportunities. Trends Ecol. Evol. 32, 464-474.

Richardson, D.M., Pyšek, P., 2006. Plant invasions: merging the concepts of species invasiveness and community invasibility. Prog. Phys. Geog 30, 409-431.

Richardson, D.M., Pyšek, P., 2008. Fifty years of invasion ecology - the legacy of Charles Elton. Divers. Distrib. 14, 161-168.

Richardson, D.M., Ricciardi, A., 2013. Misleading criticisms of invasion since: a field guide. Divers. Distrib. 19, 1461-1467.

Richardson, D.M., Carruthers, J., Hui, C., Impson, F.A.C., Miller, J.T., Robertson, M.P. Rouget, M., Le Roux, J.J., Wilson, J.R.U., 2011. Human-mediated introductions of Australian acacias - a global experiment in biogeography. Divers. Distrib. 17, $771-787$.

Rockström, J., Steffen, W., Noone, K., Persson, Å., Chapin III, F.S., Lambin, E. Lenton, T., Scheffer, M., Folke, C., Schellnhuber, H.J., Nykvist, B., 2009. Planetary boundaries: exploring the safe operating space for humanity. Ecol. Soc. 14, 32.

Russel, J.C., Blackburn, T., 2017. The rise of invasive species denialism. Trends Ecol. Evol. 32, 3-6.

Schüttler, E., Rozzi, R., Jax, K., 2011. Towards a societal discourse on invasive species management: a case study of public perceptions of mink and beavers in Cape Horn. J. Nat. Conserv. 19, 175-184.

Seastedt, T.R., 2014. Biological control of invasive plant species: a reassessment for the Anthropocene. New Phytol. 205, 490-502.

Shackleton, C.M., Gambiza, J., 2008. Social and ecological trade offs in combating land degradation: the case of invasion by a woody shrub (Euryops floribundus) at Macubeni, South Africa. Land Degrad. Dev. 19, 454-464.

Shackleton, C.M., Shackleton, R.T., 2016. Knowledge, perceptions and willingness to control designated invasive tree species in urban household gardens in South Africa. Biol. Invasions 18, 1599-1609.

Shackleton, R.T., Richardson, D.M., Shackleton, C.M., Bennet, B., Crowley, S., DehnenSchmutz, K., Estévez, R., Fisher, A., Kueffer, C., Kull, C.A., Marchante, E., Novoa, A. Potgieter, L., Vaas, J., Vaz, A.S., Larson, B.H.L., 2018a. Explaining people's perceptions of invasive alien species: a conceptual framework. J. Environ. Manage. https://doi.org/10.1016/j.jenvman.2018.04.045.

Shackleton, R.T., Shackleton, C.M., Kull, C.A., 2018b. The role of invasive alien species in shaping local livelihoods and human well-being: a review. J. Environ. Manage. https://doi.org/10.1016/j.jenvman.2018.05.007.

Shackleton, R.T., Le Maitre, D.C., Richardson, D.M., 2015. Stakeholder perceptions and practices regarding Prosopis (mesquite) invasions and management in South Africa. Ambio 44, 569-581.

Shackleton, R.T., Le Maitre, D.C., van Wilgen, B.W., Richardson, D.M., 2016. Identifying barriers to effective management of widespread invasive alien trees: Prosopis species (mesquite) in South Africa as a case study. Glob. Environ. Change 38, 183-194.

Sharp, L.M., 2014. Public perspectives on genetic biocontrol technologies for controlling invasive fish. Biol. Invasions 16, 1241-1256.

Shrestha, B.B., Shretha, U.B., Sharma, K.P., Thapa-Parajuli, R.B., Devkota, A.,
Siwakoti, M., 2019. Community perception and prioritization of invasive alien plants in Chitwan-Annapurna Landscape, Nepal. J. Environ. Manage. 229, 38-47. https://doi.org/10.1016/j.jenvman.2018.06.034.

Silvertown, J., 2009. A new dawn for citizen science. Trends Ecol. Evol. 24, 467-471.

Speziale, K.L., Lambertucci, S.A., Carrete, M., Tella, J.L., 2012. Dealing with non-native species: what makes the difference in South America? Biol. Invasions 14 1609-1621.

Steffen, W., Richardson, K., Rockström, J., Cornell, S.E., Fetzer, I., Bennett, E.M., Biggs, R., Carpenter, S.R., de Vries, W., de Wit, C.A., Folke, C., 2015. Planetary boundaries: guiding human development on a changing planet. Science 347, 1259855.

Sterling, E.J., Betley, E., Sigounin, A., Gomez, A., Toomey, A., Cullman, G., Malone, C., Pekor, A., Arengo, F., Blair, M., Filardi, C. Landrigan, K., Porzecanski, A.L., 2017. Assessing the evidence for stakeholder engagement in biodiversity conservation. Biol. Conserv. 209, 159-171.

Stokes, K.E., O'Neill, K.P., Montgomery, W.I., Dick, J.T.A., Maggs, C.A., McDonald, R.A., 2006. The importance of stakeholder engagement in invasive species management: a cross-jurisdictional perspective in Ireland. Biodiv. Conserv. 15, 2829-2852.

Stringer, L., Dougill, A., Fraser, E., Hubacek, K., Prell, C., Reed, M., 2006. Unpacking "participation" in the adaptive management of social-ecological systems: a critical review. Ecol. Soc. 11.

Tassin, J., Kull, C.A., 2015. Facing the broader dimensions of biological invasion. Land Use Pol. 42, 165-169.

Touza, J., Pérez-Alonso, A., Chas-Amil, M.L., Dehnen-Schmutz, K., 2014. Explaining the rank-order of invasive plants by stakeholder groups. Ecol. Econ. 105, $330-341$.

Trumbo, C.W., Shanahan, J., 2000. Social research on climate change: where we have been, where we are, and where we might go. Pub. Und. Sci. 9, 199-204.

Turner II, B.L., Esler, K.J., Bridgewater, P., Tewksbury, J., Sitas, N.J., Abrahams, B., Stuart Chapin II, F., Chowdhury, R.R., Christie, P., Diaz, S., Firth, P., Knapp, C.N., Kramer, J., Leemasn, R., Palmer, M., Pietri, D., Pittman, J., Sarukhán, J., Shackleton, R., Seilder, R., van Wilgen, B., Mooney, H., 2016a. Socio-Environmental Systems (SES) Research: what have we learned and how can we use this information in future research programs. Curr. Opin. Env. Sust. 19, 160-168.

Turner, R.K., Palmieri, M.G., Luisetti, T., 2016b. Lessons from the construction of a climate change adaptation plan: a Broads wetland case study. Integrated Environ. Assess. Manage 12, 719-725.

Udo, N., Darrot, C., Atlan, A., 2019. From useful to invasive, the status of gorse on Reunion Island. J. Environ. Manage. 229, 166-173. https://doi.org/10.1016/j. jenvman.2018.06.036.

van der Wal, R., Fischer, A., Selge, S., Larson, B.M., 2015. Neither the public nor experts judge species primarily on their origins. Environ. Conserv. 42, 349-355.

van Wilgen, B.W., Richardson, D.M., 2012. Three centuries of managing introduced conifers in South Africa: benefits, impacts, changing perceptions and conflict resolution. J. Environ. Manage 106, 56-68.

van Wilgen, B.W., Richardson, D.M., 2014. Managing invasive alien trees: challenges and trade-offs. Biol. Invasions 16, 721-734.

Vane, M., Runhaar, H.A.C., 2016. Public support for invasive alien species eradication programs: insights from The Netherlands. Restor. Ecol 24, 743-748.

Vaz, A.S., Kueffer, C., Kull, C.A., Richardson, D.M., Vicente, J.R., Kühn, I., Schröter, M., Hauck, J., Bonn, A., Honrado, J.P., 2017a. Integrating ecosystem services and disservices: insights from plant invasions. Ecosyst. Serv. 23, 94-107.

Vaz, A.S., Kueffer, C., Kull, C.A., Richardson, D.M., Schindler, S., Muñoz-Pajares, Vicente, J.R., Martins, J., Hui, C., Kühn, I., Honrado, J.P., 2017b. The progress of interdisciplinary in invasion science. Ambio 46, 428-442.

Villatoro, F.J., Naughton-Treves, L., Sepúlveda, M., Stowhas, P., Mardones, F., Silva-Rodríguez, E.A., 2019. When free-ranging dogs threaten wildlife: public attitudes toward management strategies in southern Chile. J. Environ. Manage. 229, 67-75. https://doi.org/10.2016/j.jenvman.2018.06.035.

Vitousek, P.M., Mooney, H.A., Lubchenco, J., Melillo, J.M., 1997. Human domination of the earth's ecosystems. Science 277, 494-499.

Wald, D.M., Nelson, K.A., Gawel, A.M., Rogers, H.S., 2019. The role of trust in public attitudes of invasive species management on Guam: a case study. J. Environ. Manage. 229, 133-144. https://doi.org/10.1016/j.jenvman.2018.06.047.

Wenger, E., 1998. Communities of Practice: Learning, Meaning, and Identity. Cambridge University Press.

Wesselink, A., Paavola, J., 2011. Rational for public participation in environmental policy and governance: practitioners' perspectives. Environ. Plan. 43, $2688-2704$

Woodford, D.J., Richardson, D.M., MacIsaac, H.J., Mandrak, N.E., van Wilgen, B.W., Wilson, J.R.U., Weyl, O.L.F., 2016. Confronting the wicked problem of managing biological invasions. NeoBiota 31, 63-86.

Zengenya, T., Ivey, P., Woodford, D.J., Weyl, O., Novoa, A., Shackleton, R., Richardson, D., van Wilgen, B., 2017. Managing conflict-generating invasive species in South Africa: challenges and trade-offs. Bothalia 47, a2160. 